\title{
Large-scale blue crab recruitment: linking postlarval transport, post-settlement planktonic dispersal, and multiple nursery habitats
}

\author{
Lisa L. Etherington*, David B. Eggleston
}

North Carolina State University, Department of Marine, Earth and Atmospheric Sciences, Raleigh, North Carolina 27695, USA

\begin{abstract}
A large-scale study of early juvenile blue crab Callinectes sapidus recruitment within a shallow, predominantly wind-driven estuarine system demonstrated that distribution and abundance patterns were jointly influenced by location from oceanic sources of postlarvae, time period, habitat type, and post-settlement planktonic dispersal. The Croatan-Albemarle-Pamlico Estuarine System (CAPES) in North Carolina, USA, is a lagoonal body of water that is separated from the Atlantic Ocean by a chain of barrier islands, which are bisected by Oregon, Hatteras, and Ocracoke Inlets. For sampling purposes, the CAPES was divided into 4 regions that differed in distance and orientation from oceanic sources of postlarvae, as well as available complex benthic habitat types. The Eastern region was closest to oceanic waters, contained 3 major inlets, and harbored extensive seagrass beds. The Northern and Western regions were located along the inland boundary of the CAPES, and contained alternative habitat types including the submersed rooted vascular plant Myriophyllum spicatum and shallow detrital habitats. The Southern region was inshore and contained patchy seagrass. During a period that lacked storm events, virtually all juvenile recruitment occurred within seagrass beds at the Eastern region. Conversely, early juvenile blue crabs were distributed widely throughout the CAPES after the passage of tropical cyclones. The Eastern region appears to act as a relatively consistent initial recruitment site, whereas Northern and Western regions of the CAPES may act as episodic recruitment areas after the passage of tropical cyclones. Similar densities of early juveniles were found in different complex benthic habitats (seagrass, shallow detrital habitat, M. spicatum). A comparison of site-specific, settler-recruit densities (which represent distinct cohorts) suggested that post-settlement juveniles dispersed planktonically throughout the CAPES, most likely due to stormdriven transport. Post-settlement, planktonic dispersal altered the settler-recruit relationship, by both masking and potentially enhancing a density-dependent relationship between settlers and recruits. This study illustrates that ecological processes influencing recruitment, such as post-settlement dispersal, may be missed when studied at relatively small spatial scales, and that our interpretation of population regulation can vary depending on the scale of study. Studies conducted over broad spatial scales can provide a more complete understanding of recruitment dynamics and can elucidate the interconnectedness of subpopulations by identifying potential 'source' areas in species with open populations.
\end{abstract}

KEY WORDS: Blue crab · Recruitment - Nursery habitats $\cdot$ Post-settlement dispersal $\cdot$ Post-larval dispersal $\cdot$ Density-dependence $\cdot$ Hurricanes $\cdot$ Seagrass

\section{INTRODUCTION}

A fundamental issue in ecology is to understand the linkages between ecological patterns and processes occurring at different spatial and temporal scales

*E-mail: lletheri@unity.ncsu.edu
(Roughgarden et al. 1988). Because marine species with complex life cycles (i.e., species with 2 or more life stages occupying spatially distinct habitats) possess dispersive stages that interconnect subpopulations, many marine populations are likely to occupy 'source' and 'sink' habitats (Pulliam 1988). 'Source' habitats or areas consistently harbor high densities, and emigration from 
these areas is crucial in sustaining the regional population, whereas 'sinks' contain populations which cannot persist without input from source areas (Pulliam 1988, Lipcius et al. 1997). This conceptual approach for examining population dynamics emphasizes the need to examine recruitment over broad spatial and fine temporal scales to understand linkages between regions of varying recruitment and habitat quality.

Recruitment of marine species with complex life cycles is typically influenced by a combination of physical and biological factors acting upon the early developmental stages. Much of the work concerning spatiotemporal variability in recruitment in marine systems has focused on either sessile invertebrates residing on hard substrata (Connell 1985, Gaines et al. 1985, Roughgarden et al. 1988, Gaines \& Bertness 1992, review by Booth \& Brosnan 1995), or coral reef fishes (Victor 1986, Planes et al. 1993, Doherty \& Fowler 1994, review in Booth \& Brosnan 1995); however, there is a growing body of information on recruitment within soft-substrate systems (review by Olafsson et al. 1994). Olafsson et al. (1994) suggest that post-settlement processes play a significant role in population regulation within soft-substrate systems, and that larval supply is not the main determinant of animal abundance. Because recruitment is often extremely variable, both spatially and temporally, subsequent abundance patterns are often highly dependent upon the scale at which they are measured. Patterns apparent at one scale can decouple when viewed from other scales (Tolimieri 1995, Thrush et al. 1997).

Previous research indicates that postlarval settlement of the blue crab Callinectes sapidus exhibits high spatial and temporal variability within the CroatanAlbemarle-Pamlico Estuarine System (CAPES) in North Carolina (Eggleston et al. unpubl.). In general, consistently high rates of settlement have been observed within the Eastern region of the estuary, which is nearest to oceanic sources of larvae (Eggleston et al. unpubl.). The inland (western) region is characterized by periods of virtually no postlarval settlement interrupted by episodic peaks associated with the passage of tropical cyclones. Understanding spatiotemporal recruitment variability in the blue crab is of particular interest because of the commercial and ecological importance of the species.

One of the goals of the present study was to assess the relationship between spatiotemporal variability in postlarval settlement (Eggleston et al. unpubl.) and early juvenile abundance (this study) in the blue crab within the CAPES. In addition, we were interested in how spatial variability in various habitat types influenced spatial patterns of juvenile recruitment. We hypothesized that the Eastern region would be an area of relatively high recruitment of juvenile blue crabs due to consistent postlarval supply and presence of extensive seagrass beds. We also predicted that despite the episodic transport of blue crab postlarvae to Northern and Western region stations within the CAPES due to tropical cyclones, few, if any, early juveniles would be collected due to a lack of seagrass nursery habitat.

Although extensive research on blue crab recruitment dynamics has been conducted in tidally-driven estuarine systems, such as the Chesapeake Bay (e.g., Orth \& van Montfrans 1987, Goodrich et al. 1989, Olmi 1994, Pile et al. 1996) and Delaware Bay (e.g., Epifanio et al. 1984), little information exists on the distribution and abundance of early juvenile blue crabs in relatively shallow, predominantly wind-driven lagoonal systems, such as found in North Carolina, USA (but see Thomas et al. 1990 and Williams et al. 1990 for smaller lagoonal systems in the Gulf of Mexico). Within such a system, the likely dependence of recruitment on stochastic wind forcing, compared with tidally driven systems, could lead to more variability in spatiotemporal distribution and abundance of early juveniles.

In the Chesapeake Bay, the settlement and nursery habitat for blue crabs is primarily seagrass (Heck \& Thoman 1981, Orth \& van Montfrans 1987); however, other vegetated habitats such as salt marshes may also provide adequate nursery habitat in other areas (Thomas et al. 1990, Wilson et al. 1990a, review by Zimmerman et al. 2000). Seagrass is a primary nursery habitat for numerous species of fish and invertebrates throughout the world (reviews in Orth et al. 1984 and Orth 1992). Nevertheless, with the extensive loss of seagrass in many coastal areas throughout the world, attention has turned to 'alternative' habitats that may provide nursery functions similar to those of seagrass habitats. Structurally complex habitats such as oyster shell (Wells 1961, Fernandez et al. 1993, Eggleston \& Armstrong 1995, Eggleston et al. 1998a, Eggleston et al. 1999, Posey et al. 1999), cobble (Wahle \& Steneck 1991), marsh peat reefs (Able et al. 1988), macroalgae (Wilson et al. 1990a,b, Dorf \& Powell 1997), and coarse woody debris (Everett \& Ruiz 1993) provide refuge and support high densities of estuarine macrofauna. Although unstructured shallow areas provide an alternative refuge for blue crabs in estuarine systems lacking seagrass (Ruiz et al. 1993, Dittel et al. 1995), there is relatively little information on abundance patterns of early juvenile blue crabs in alternative, structurally complex estuarine habitats (but see Wilson et al. 1990a, Everett \& Ruiz 1993, Eggleston et al. 1998a). In this study, we examined how postlarval transport, post-settlement planktonic dispersal, and multiple nursery habitats influenced distribution and abundance patterns of early juvenile blue crabs Callinectes sapidus in North Carolina, USA. 


\section{METHODS}

Our examination of recruitment dynamics of early juvenile blue crabs focused on 3 main categories of data: (1) spatiotemporal variation in juvenile crab abundance; (2) habitat-specific abundance; and (3) settler-recruit relationships.

Blue crab life-history. Like many marine invertebrates, the blue crab Callinectes sapidus exhibits a complex life cycle. Larvae released by females at bay mouths and inlets are transported to the continental shelf where they develop through 7 to 8 larval stages (van Engel 1958). Larval development lasts about $1 \mathrm{mo}$, at which time the larvae metamorphose to a postarva (megalopa) on the nearshore shelf (van Engel 1958, Epifanio et al. 1984). Postlarvae are then transported inshore by wind and tidal currents (Epifanio et al. 1984, Goodrich et al. 1989). Once postlarvae reinvade the estuaries, they settle into shallow water habitats, and then metamorphose to the first benthic instar stage (J1). In North Carolina, there appears to be 2 seasonal peaks of recruitment-a minor peak in May (S. McKenna, North Carolina Division of Marine Fisheries, pers. comm.) followed by a larger peak from August to November (Eggleston et al. unpubl.).

Study system and sites. The Croatan-AlbemarlePamlico Estuarine System (CAPES; Fig. 1) in North Carolina, is the largest lagoonal system in the United States, and serves as an important nursery and adult habitat for numerous estuarine-dependent species (Ross \& Epperly 1985). This shallow system (mean water depth $=5 \mathrm{~m}$ ) is separated from the Atlantic Ocean by a series of barrier islands known as the 'Outer Banks'. The CAPES contains 3 major inlets (Oregon, Hatteras, and Ocracoke Inlets), which serve as sources of ocean-spawned larvae. Circulation within the CAPES is predominantly wind-driven; tidal forcing occurs only within 3 to $5 \mathrm{~km}$ of the inlets (Pietrafesa \& Janowitz 1991, Tom Hopkins, North Carolina State University, pers. comm.).

The density of early juvenile blue crabs was measured at 9 sites spanning the perimeter of the estuary, which equals approximately $500 \mathrm{~km}$ of shoreline within the CAPES (Fig. 1). Three sampling sites were located adjacent to inlets along the barrier islands: Oregon, Hatteras, and Ocracoke Inlets, and will be periodically referred to as 'Eastern region' stations (Fig. 1). Two 'Northern region' stations included Point Harbor and Manns Harbor that were located in Albemarle and Croatan Sounds, respectively (Fig. 1). Engelhard and Swanquarter comprised the 'Western region' stations and were located along the western shore of Pamlico Sound
(Fig. 1). The 'Southern region' consisted of the Oriental and Cedar Island stations that were located in the southern portion of Pamlico Sound (Fig. 1). Water depths across the 9 stations range from 0.25 to $1.0 \mathrm{~m}$.

Sampling methodology. The density of early juvenile blue crabs was quantified by benthic suction sampling in complex habitats (seagrass [SG], shallow detrital habitat $[\mathrm{SDH}]$, submersed rooted vascular plants [SRV]), and unstructured bottoms (UNST) at each of 9 sites, during the first quarter of the new moon in August, September, and October 1996 (Table 1, Fig. 1). Greater numbers of blue crab postlarvae have been

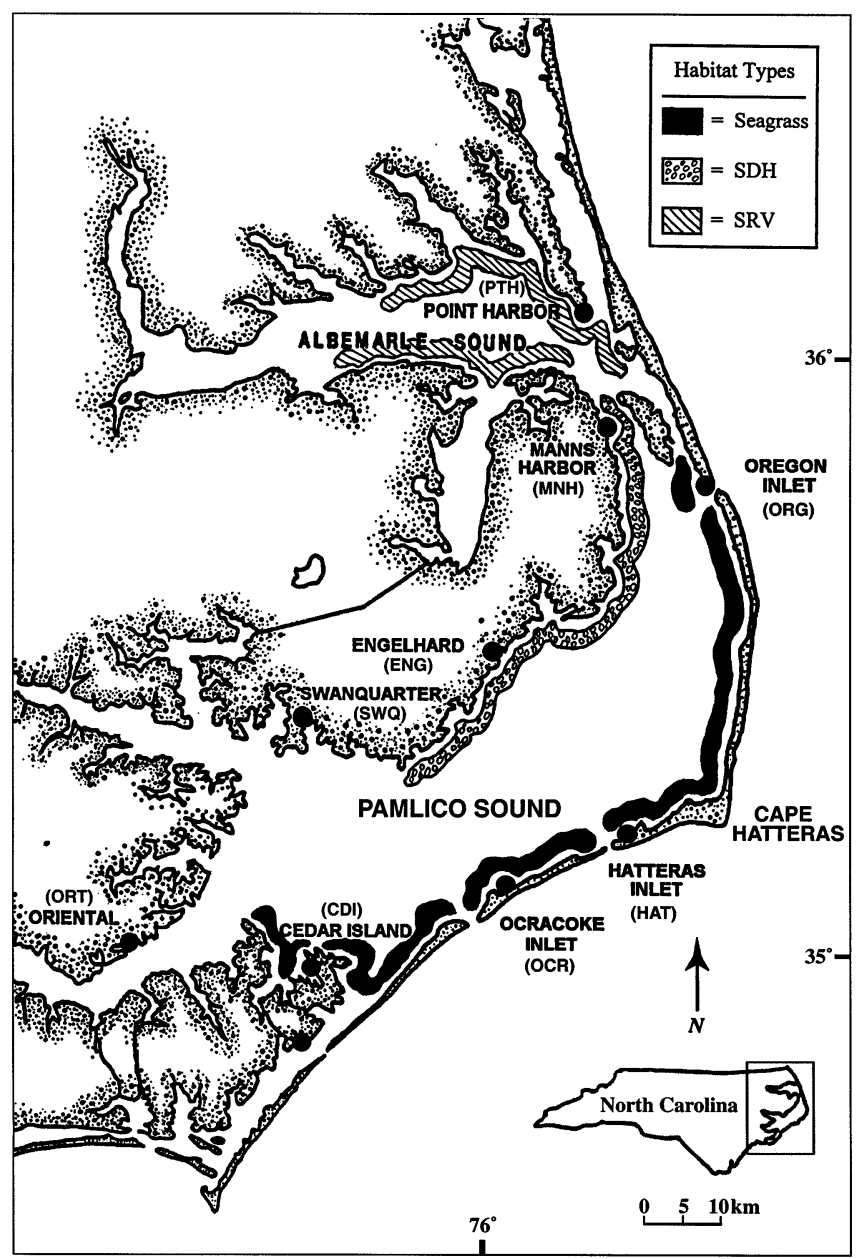

Fig. 1. Croatan-Albemarle-Pamlico Estuarine System (CAPES) in North Carolina, USA, with the locations of 9 blue crab sampling sites. Eastern region: Oregon, Hatteras and Ocracoke Inlets. Northern region: Point Harbor and Manns Harbor. Western region: Engelhard and Swanquarter. Southern region: Cedar Island and Oriental. Croatan Sound is not labeled, but is the connecting body of water between Pamlico and Albemarle Sounds, just east of Manns Harbor. Approximate cover of 3 complex habitat types (seagrass [SG], shallow detrital habitat [SDH], submersed rooted vasculars [SRV]) within the CAPES as modified from Ferguson \& Wood (1994). (Table 1) 
Table 1. Sites and habitats sampled for early juvenile blue crabs within the CAPES during August, September, and October 1996. SG: seagrass (Zostera marina, Halodule wrightii, and Ruppia maritima); SRV: submersed rooted vascular plants (primarily Myriophyllum spicatum); SDH: shallow detrital habitat; and UNST: unstructured bottom (Fig. 1)

\begin{tabular}{|c|c|c|}
\hline Site & Site code & Habitats sampled \\
\hline \multicolumn{3}{|l|}{ Eastern region } \\
\hline Oregon Inlet & ORG & SG; UNST \\
\hline Hatteras Inlet & HAT & SG; UNST \\
\hline Ocracoke Inlet & OCR & SG; UNST \\
\hline \multicolumn{3}{|l|}{ Northern region } \\
\hline Point Harbor & PTH & SRV; UNST \\
\hline Manns Harbor & $\mathrm{MNH}$ & $\begin{array}{l}\text { SG: Aug; SDH: Sep and } \\
\text { Oct; UNST }\end{array}$ \\
\hline \multicolumn{3}{|l|}{ Western region } \\
\hline Engelhard & ENG & $\begin{array}{l}\text { SG; SDH-Sep and Oct; } \\
\text { UNST }\end{array}$ \\
\hline Swanquarter & SWQ & SG; UNST \\
\hline \multicolumn{3}{|l|}{ Southern region } \\
\hline Oriental & ORT & SG; UNST \\
\hline Cedar Island & CDI & SG; UNST \\
\hline
\end{tabular}

collected in North Carolina around new moon periods (Mense et al. 1995), thus the sampling period was chosen to maximize the chance of detecting peaks of recently settled juveniles (J1-J2). Seagrasses consisted of Zostera marina, Halodule wrightii, and Ruppia maritima. Although SRV is a general term describing all submersed rooted vascular plants (including seagrasses) (Ferguson \& Wood 1994), we distinguish between SRV (primarily Myriophyllum spicatum) and seagrasses based on extreme differences in morphology and growth strategies, as well as occurrence within the CAPES. For example, seagrasses are characterized by thin, 2-dimensional leaves that originate from the substrate surface and are typically 3 to $12 \mathrm{~cm}$ in height at our study sites. Seagrass is found in dense beds along the sound-side of the Outer Banks (Eastern region), as well as at Cedar Island within the Southern region (Fig. 1; Ferguson \& Wood 1994). Sparse, isolated patches of seagrass also occur along the Western region and at the Oriental site within the Southern region. In contrast to seagrasses, individual $M$. spicatum plants extend from the substrate to the surface of the water, often reaching 1.0 to $1.5 \mathrm{~m}$ in height, and consist of filamentous leaves that branch off along the main stalk of the plant. M. spicatum is prolific within the oligohaline waters of Albemarle and Currituck Sounds (Fig. 1). Shallow detrital habitats resemble finely ground peat material with embedded stems and rhizomes of saltmarsh grasses, and occurred in 3 to $8 \mathrm{~m}$ bands parallel to the erosional edge of saltmarsh habitats along the western region of the CAPES (Fig. 1).
This habitat type can be subtidal to intertidal depending upon wind-driven water levels (L.L.E. pers. obs.). $\mathrm{SDH}$ areas appear to be associated with high energy regimes, which cause the exposed edges of a salt marsh to erode, thereby leaving a dense mat of peat and root mass, 1 to $3 \mathrm{~cm}$ in vertical relief.

Sampling of all 9 sites was conducted within a $5 \mathrm{~d}$ period, beginning $3 \mathrm{~d}$ after the new moon. Within each site, 6 samples were taken from each of the complex benthic habitats present (SG, SDH, SRV), as well as 2 samples from unstructured bottom. Suction sampling was conducted according to protocols described in Orth \& van Montfrans (1987), which determined the sampling efficiency for this gear type to be $88 \%$ in seagrass. Further gear efficiency studies modified the sampling protocol to decrease the sampling area as well as the sampling time (Pile et al. 1996). Since the shallow detrital habitat and Myriophyllum spicatum are more complex than seagrass, we assumed that the efficiency of capture of juvenile blue crabs within these habitats would be lower, and thus our measures of abundance in SDH and SRV would be conservative.

Sampling was conducted using a suction dredge apparatus with $790 \mu \mathrm{m}$ mesh collection bags. Sampling rings, which enclosed $1.674 \mathrm{~m}^{2}$ of the bottom, were haphazardly thrown into a continuous area of a specified habitat. If a continuous area was not available, samples were taken from the interior of the largest patches present. In the case of the $\mathrm{SDH}$, suction samples were taken in very shallow water $(\sim 20 \mathrm{~cm}$ in depth) parallel to shore. Each sample consisted of 6 min of suctioning, followed by dip-netting until 3 consecutive sweeps contained no decapod crustaceans or fish.

To assess the influence of seagrass characteristics on blue crab abundance, a $7.5 \mathrm{~cm}$ diameter core was taken immediately outside of the suction ring for each sample. Vegetated matter was sieved and frozen. Seagrass species were identified in the laboratory and a subsample of 10 leaves was measured and dried at $45^{\circ} \mathrm{C}$ for $48 \mathrm{~h}$. This procedure provided the following estimates for each sample: (1) above-ground biomass (g per $442 \mathrm{~m}^{2}$ ); (2) number of short shoots (no. per $\left.442 \mathrm{~m}^{2}\right)$; and (3) average leaf length $(\mathrm{mm})$. Core samples were inappropriate for the SRV Myriophyllum spicatum, due to its extensive vertical height (1.0 to $1.5 \mathrm{~m})$. Instead, a biomass estimate $(\mathrm{g})$ was obtained from the plant matter removed during suctioning, since the suctioning process removed nearly all the plant material from the enclosed area. The biomass of M. spicatum was dried at $45^{\circ} \mathrm{C}$ for $48 \mathrm{~h}$. As a measure of SDH complexity, the displacement volume of material removed during each suction sample was quantified. Temperature and salinity were recorded concurrently with each month's sampling at all 9 sites. Data 
on tropical cyclone events occurring within $210 \mathrm{~km}$ of the North Carolina CAPES (the distance from shore that a tropical cyclone can have an impact on water level heights within the CAPES; see Eggleston et al. unpubl.) were collected from the U.S. National Weather Service throughout the recruitment period.

Sample processing. Suction samples were either stored in $70 \%$ ethyl alcohol or immediately frozen. Blue crabs were counted and size was measured as carapace width $\left(\mathrm{CW}_{;}\right.$the width between the tips of the lateral spines). Crabs $<10 \mathrm{~mm} \mathrm{CW}$ were measured with an ocular micrometer, whereas individuals $>10 \mathrm{~mm}$ were measured with calipers.

The number of suction samples processed within the seagrass category at some sites was reduced to 3 , due to extremely low abundances of crabs, as well as low variance among replicates (range of mean \pm SE: $0.33 \pm$ 0.33 to $9.33 \pm 2.96$ ). This sample processing protocol was also applied to the October SDH samples from Manns Harbor, where total numbers of juveniles were very low, and hence the number of samples processed was also reduced to 3 (mean \pm SE: $11.33 \pm 0.88$ ). To decrease sample processing time, seagrass sample size was reduced to 5 within sites that contained relatively high densities of juveniles and low variance among replicates (range of mean \pm SE: $8.6 \pm 0.7$ to $138.6 \pm 19.1$ ) .

Statistical analyses. Spatiotemporal variation in abundance of recent settlers and early recruits: Juvenile instars 1 and 2 (J1-J2) represent recent settlers (0 to $16 \mathrm{~d}$ since settlement), instars 3 through 5 (J3-J5) were grouped as early recruits (14 to $46 \mathrm{~d}$ since settlement), and instars 6 through 9 (J6-J9) were classified as later recruits (41 to $113 \mathrm{~d}$ since settlement) (Tables 2 \& 3). Instar size categories were modeled after Pile et al. (1996), in which the results from several growth studies were integrated to arrive at non-overlapping size classes for each instar (Table 2), while time-since-settlement was calculated using the confidence intervals about mean intermolt periods from Millikin \& Williams (1980) (Table 3).

To examine variation in J1-J2 and J3-J5 blue crab densities between sites within the CAPES and over time, we selected the habitat within a given sampling site and month that contained the highest densities of crabs. This method was chosen to compare juvenile recruitment between sites since all habitat types were not represented at every site. Therefore, the calculated site means represent 'peak potential recruitment' to each site throughout the recruitment season. We tested whether or not J1-J2 and J3-J5 blue crabs varied between sites (nine sites) and over time (August, September, October) with 2 separate fixed factor, 2-way ANOVA models. The J6-J9 size class was excluded from this particular analysis due to extremely low numbers at certain sites. Moreover, given that we sometimes observed size-specific differences in habitat use, we used univariate analyses with 2 separate 2-way ANOVA models (J1-J2 and J3-J5), rather than a single multivariate ANOVA model. A fixed-factor model was used because sites were chosen to represent distinct locations within the sound system that differed in terms of their orientation and distance from oceanic sources of postlarvae. The months of August to October were chosen based on previous blue crab recruitment studies, which showed highest postlarval influx during this period (Mense et al. 1995, van Montfrans et al. 1995). Samples taken from different months within the same site can be treated as independent since the location of a particular sample was chosen haphazardly from numerous positions within a large area of available habitat, and juveniles (J1-J2 and J3-J5 instars) would grow out of their instar category before the next month's sampling period. The assumption of homogeneity of variances was tested with Cochran's $C$-test and resulted in $\log (x+1)$ transformation of J1-J2 stages and square root transformation of J3-J5 stages. Means were contrasted with Ryan's $Q$ multiple comparison tests.

Table 2. Size of benthic instars (spine-to-spine carapace width [CW]) used to categorize juvenile blue crabs (Pile et al. 1996)

\begin{tabular}{|lc|}
\hline Instar & CW $(\mathrm{mm})$ \\
\hline First & $2.2-3.0$ \\
Second & $3.1-4.2$ \\
Third & $4.3-5.9$ \\
Fourth & $6.0-7.4$ \\
Fifth & $7.5-9.1$ \\
Sixth & $9.2-10.6$ \\
Seventh & $10.7-12.6$ \\
Eighth & $12.7-14.1$ \\
Ninth & $14.2-16.1$ \\
\hline
\end{tabular}

Table 3. Intermolt periods during early juvenile development of blue crabs reared in the laboratory (Millikin unpubl. results in Millikin \& Williams 1980). Mean \pm SD of the number of days between molt instars during juvenile development. Numbers of crabs sampled for each intermolt period are in parentheses

\begin{tabular}{|cr|}
\hline $\begin{array}{c}\text { Instar } \\
\text { juvenile stages }\end{array}$ & $\begin{array}{c}\text { Mean intermolt } \\
\text { period in days }\end{array}$ \\
\hline $1-2$ & $7.2 \pm 2.7(104)$ \\
$2-3$ & $7.6 \pm 3.0(157)$ \\
$3-4$ & $8.0 \pm 2.5(157)$ \\
$4-5$ & $9.2 \pm 3.8(157)$ \\
$5-6$ & $11.1 \pm 4.2(157)$ \\
$6-7$ & $12.6 \pm 2.8(157)$ \\
$7-8$ & $14.7 \pm 5.1(156)$ \\
$8-9$ & $16.6 \pm 4.6(156)$ \\
\hline
\end{tabular}


Habitat-specific abundance patterns: General habitat comparisons of crab abundance. Habitat-specific abundance patterns of J1-J2 and J3-J5 blue crabs were assessed by pooling abundance measures across all sites (except Cedar Island and Oriental) and the months of September and October. Cedar Island and Oriental were removed from this analysis due to a consistent lack of individuals in both size classes at these sites throughout the recruitment season. August was excluded from this analysis because all habitat types were not sampled during this month (Table 1 ; SDH was not sampled). Two separate, 2-way ANOVA models assessed the influence of Habitat type (SG, SDH, SRV, UNST) and Month (September, October) on mean abundance of J1-J2 and J3-J5 blue crabs. Analysis of the J6-J9 class was excluded due to low abundances. Despite multiple transformations, the variances associated with the J1-J2 and J3-J5 size classes remained heteroscedastic (Cochran's $C$-test). Thus, hypotheses were rejected at alpha values lower than the $p$ value of the test for homogeneity of variance (Underwood 1981). Ryan's $Q$ multiple comparison tests identified differences in crab abundance between habitat types.

Comparisons of crab abundance between complex habitats within a site. Engelhard was the only site that contained more than 1 structurally complex habitat (SG and SDH) at the same sampling time. Within this site, the effect of sampling Month (September and October) and Habitat type (SG and SDH) on mean abundance of J1-J2 and J3-J5 instar blue crabs was examined with 2 separate, 2-way ANOVA models. A protected, lower-level ANOVA was used to interpret significant Habitat type $\times$ Month interaction effects (see 'Results' below).

Habitat complexity. Analysis of covariance models were used to examine the response of early juvenile crab densities to varying habitat complexity, for 3 separate habitat types: (1) SG; (2) SRV; and (3) SDH. We restricted our analyses of the effects of seagrass characteristics on crab abundance to the Eastern region because there were higher numbers of juveniles in all 3 size classes (J1-J2, J3-J5, J6-J9) within this region, and seagrass species composition was similar between sites. We determined the effects of seagrass characteristics on J1-J2 and J3-J5 blue crab abundance with 2 separate 2-way ANCOVA models with Site (ORG, HAT, OCR) and Month (August, September, October) as factors, and average leaf length, seagrass biomass, and number of shoots as 3 separate covariates. The response variable of J6-J9 instars could not be considered independent from 1 mo to the next since the time to grow out of this size category is longer than one month (see intermolt periods in Table 3). Therefore, the analysis of the influence of seagrass characteristics on J6-J9 instars was conducted with a repeated mea- sures ANCOVA model with replicates nested within Site as the experimental subject which was repeated over time, Month and Site as factors, and seagrass biomass, number of shoots, and mean leaf length as 3 separate covariates. Initially, the full ANCOVA models included all Main factor $\times$ Covariate interaction terms (Underwood 1981); however, these interaction terms were non-significant (all $\mathrm{p}>0.07$ ), and were therefore dropped from the final model.

Within the Point Harbor site, we examined the effects of SRV structure on J1-J2 and J3-J5 crab instars using two separate 1-way ANCOVA models, with Month (August, September, October) as the main factor and SRV biomass as a covariate. The J6-J9 stage was excluded from this analysis due to extremely low abundances. As above, the Main factor $\times$ Covariate interaction terms were non-significant (all $\mathrm{p}>0.27$ ), and were therefore dropped from the final models.

We examined the influence of SDH complexity on juvenile crab densities for J1-J2 and J3-J5 instars with 2 separate 2-way ANCOVA models with Site (MNH and ENG) and Month (September and October) as factors, and the displacement volume of $\mathrm{SDH}$ as the covariate. Again, J6-J9 individuals were not included in this analysis due to extremely low abundances. All Factor $\times$ Covariate interaction terms were non-significant (all $p>0.25$ ), and were therefore dropped from the final models.

Settler-recruit relationships: We examined the relationship between J1-J2 instars (settlers) and successive J5 instars (recruits) for evidence of density-dependence. Our intent was not to measure continuous recruitment throughout the season, but instead to analyze the settler-recruit relationship by following distinct cohorts over time. We followed the fate of individual cohorts throughout the 3 mo sampling period by back-calculating time-since-settlement using interinstar molt intervals (Table 3). For example, J1-J2 crabs collected in August settled between 0 and $16 \mathrm{~d}$ prior to our new moon sampling period (Fig. 2). This window of settlement also corresponded with J5 instars collected in September, which would have settled between 30 and $46 \mathrm{~d}$ prior to our September sampling time (Fig. 2). This method for back-calculating time-since-settlement was also applied to subsequent sampling dates relating J1-J2 densities in September with the subsequent density of J5 juveniles collected in October. Variable growth rates between laboratory and field conditions could alter our time-since-settlement estimates, and therefore our definition of a cohort. Epifanio et al. (1994) and Welch \& Epifanio (1995) observed higher growth rates for crab larvae in field enclosures than in the laboratory. Similar growth differences may exist in juvenile crabs, causing a stage later than J5 to be matched up with J1-J2 in defining a 
cohort; however, our definition of a cohort was based upon the only available information on juvenile growth, and therefore represents the best possible estimate of a cohort.

The densities of J1-J2 and J5 were obtained from the habitat that contained the highest numbers of crabs within that site and month category, representing 'peak potential recruitment' (as described above in 'Spatiotemporal variation in abundance of recent settlers and early recruits'). To examine how the settlerrecruit relationship might vary over time, we examined inter-instar relationships between all sampling sites for 2 separate cohorts (Cohort 1: August J1-J2 and September J5; Cohort 2: September J1-J2 and October J5).

The relationship between settlers (J1-J2) and recruits (J5 of the following month) was examined by fitting a general functional response model (Real 1979, Lipcius \& Hines 1986, Eggleston 1995), as well as a linear regression model, to the data. We initially examined the data with a linearized adaptation of a functional response model derived by Real (1979) to determine whether the relationship between settlers and recruits was linear or non-linear. The model is:

$$
\log (Y / A-Y)=-\log (B)+\beta \log (X)
$$

where $Y=$ density of J5 instars, $X=$ density of $\mathrm{J} 1-\mathrm{J} 2$ instars, $A=$ asymptotic density of $\mathrm{J} 1-\mathrm{J} 2$ instars, $B=$ value of $X$ at which $Y=0.5(A)$, and $\beta=$ the parameter associated with the form of the function. When $\beta=0$, the slope is zero, when $\beta=1$ the curve is hyperbolic, and $\beta>1$ indicates the curve is sigmoid. Thus, a statistical test of the parameter $\beta$ is also a test of the form of the relationship between J1-J2 settlers and J5 recruits (Lipcius \& Hines 1986, Eggleston 1995). Estimates of $\beta$ were tested against 0,1 , and 2 with 1 tailed $t$-tests. When a linear form described the relationship, linear least squares regression was fitted to the data. When both linear and hyperbolic regression models fit the data equally well, we chose the simpler linear model. In cases where the general functional response model identified a non-linear, hyperbolic relationship between J1-J2 and J5 crabs, we fit a hyperbolic function to the data. Separate analyses were conducted for each cohort. Within each of these series of analyses, one analysis focused on all sites, whereas a second analysis used only sites that did not appear to be influenced by substantial post-settlement immigration (i.e., the ratio J1-J2:J5 > 1). For the reduced analyses involving only those sites that demonstrated a ratio of J1-J2:J5 > 1, Point Harbor, Manns Harbor, Engelhard, and Swanquarter were removed for Cohort 1, whereas Engelhard and Swanquarter were dropped from the analysis of Cohort 2 (See 'Results: Settler-recruit relationships' below).

\section{RESULTS}

\section{Environmental conditions}

Water temperatures during the study period followed decreasing seasonal trends from August through October, with August values ranging from 26.5 to $31.5^{\circ} \mathrm{C}$, and October temperatures ranging from 19 to $21^{\circ} \mathrm{C}$. Salinity also decreased from August through October across most sampling stations. Exceptions to this trend were Manns Harbor, Engelhard, and Point Harbor, which showed an increase in salinity in September, most likely as a result of increased influx of oceanic water following Hurricane 'Fran'. Salinities varied as a function of region: Eastern region 7 to

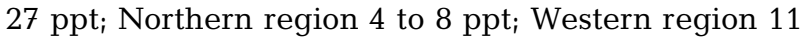
to $19 \mathrm{ppt}_{\text {; }}$ Southern region 5 to $18 \mathrm{ppt}$.

A total of 4 tropical cyclones passed within $210 \mathrm{~km}$ of the North Carolina CAPES between August 1 and October 31, 1996. Three were grouped within a $14 \mathrm{~d}$ period preceding our September sampling period: Hurricanes 'Edouard', 'Fran' and 'Hortense' (Fig. 2). These 3 hurricanes had a general S/SE to N/NW storm track which influenced water levels from the southwestern to the northern portions of the CAPES. Tropical storm 'Josephine' occurred approximately $10 \mathrm{~d}$ prior to the October sampling period (Fig. 2), and had a SW to NE storm track which influenced water levels primarily in the eastern and southern regions of the sound system. The net effect of all of these tropical cyclones was an increased volume of oceanic water into the CAPES (for further details see Eggleston et al. unpubl.).

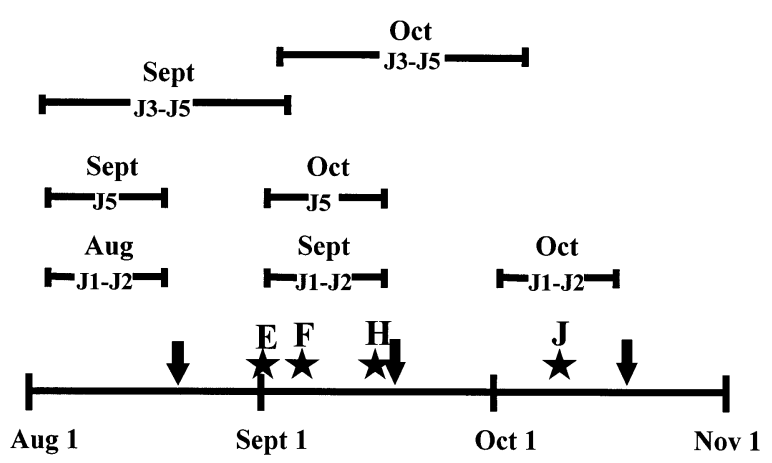

Fig. 2. Schematic illustrating sampling times, occurrence of tropical cyclones, and back-calculated settlement periods for early juvenile blue crabs. Three sampling periods are denoted by arrows and correspond to August, September, and October. Stars represent tropical cyclones: $\mathrm{E}=$ Hurricane 'Edouard', F = Hurricane 'Fran', H = Hurricane 'Hortense', and $\mathrm{J}=$ Tropical storm 'Josephine'. Using mean intermolt periods, the potential time of settlement into the CAPES was back-calculated for individuals collected each month. Settlement windows, which are specific to the instar stages as well as the month sampled, are denoted by bars that correspond to a period along the timeline 

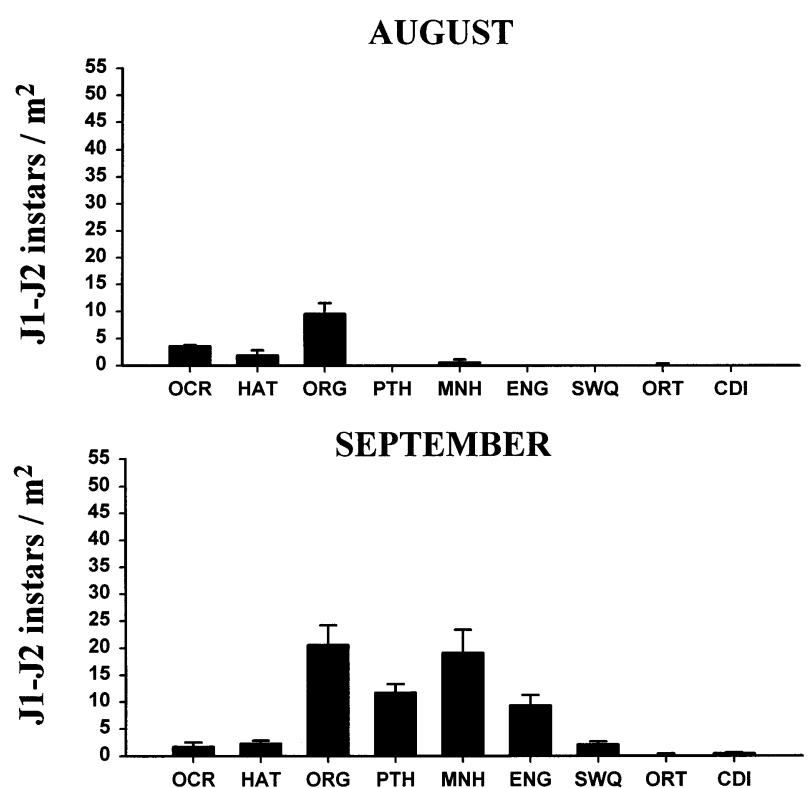

OCTOBER

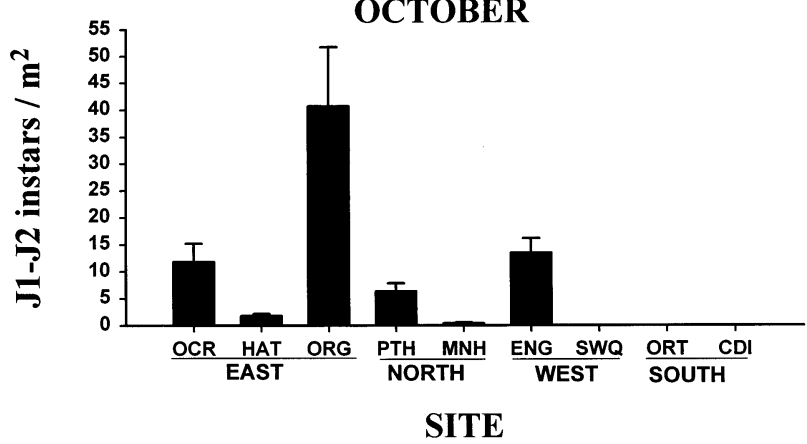

Fig. 3. Density of benthic juvenile instars 1 and 2 (J1-J2: recent settlers) as a function of Month and Site. Early juvenile densities were obtained from the habitat within each site and during a specific sampling period (Month) that contained the highest crab densities. Values are means +1 SE. (Table 4)

\section{Spatiotemporal variation in abundance of recent settlers and early recruits}

The overall distribution and abundance of early juvenile blue crabs increased in the CAPES from August to September and October, 1996 (Figs. 3 \& 4). In general, the Oregon Inlet site consistently harbored the highest densities of early juvenile blue crabs, whereas crab densities at the other sites varied as a function of month and size class. J1-J2 instar blue crabs were collected consistently at the Eastern region stations throughout the recruitment period. Blue crab settlers were virtually nonexistent within the Northern, Western, and Southern regions in August. The spatial distribution of juveniles throughout the CAPES increased in September and October. Very high densities of J1-J2 blue crabs were found in Northern and Western regions in Sep- tember, whereas moderate densities occurred within certain Northern and Western regions in October (Fig. 3). The Southern region sites had extremely low densities of J1-J2 instars in all 3 mo (Fig. 3). In terms of the J3-J5 size class, the Eastern region consistently had moderate to high densities of early juvenile blue crabs in all $3 \mathrm{mo}$, similar to the pattern observed for J1-J2 crabs (compare Figs. 3 \& 4). Densities of J3-J5 instars in August were essentially zero at Point Harbor, Swanquarter, Oriental, and Cedar Island, which was also similar to the pattern observed for J1-J2 instars in August (compare Figs. $3 \& 4$ ). The distribution and abundance of early recruits increased during September and October. Densities of J3-J5 increased to very high levels at Northern and Western regions in September; these same regions contained moderate to high densities in October, with higher densities observed at Western than Northern regions (Fig. 4). The Southern region
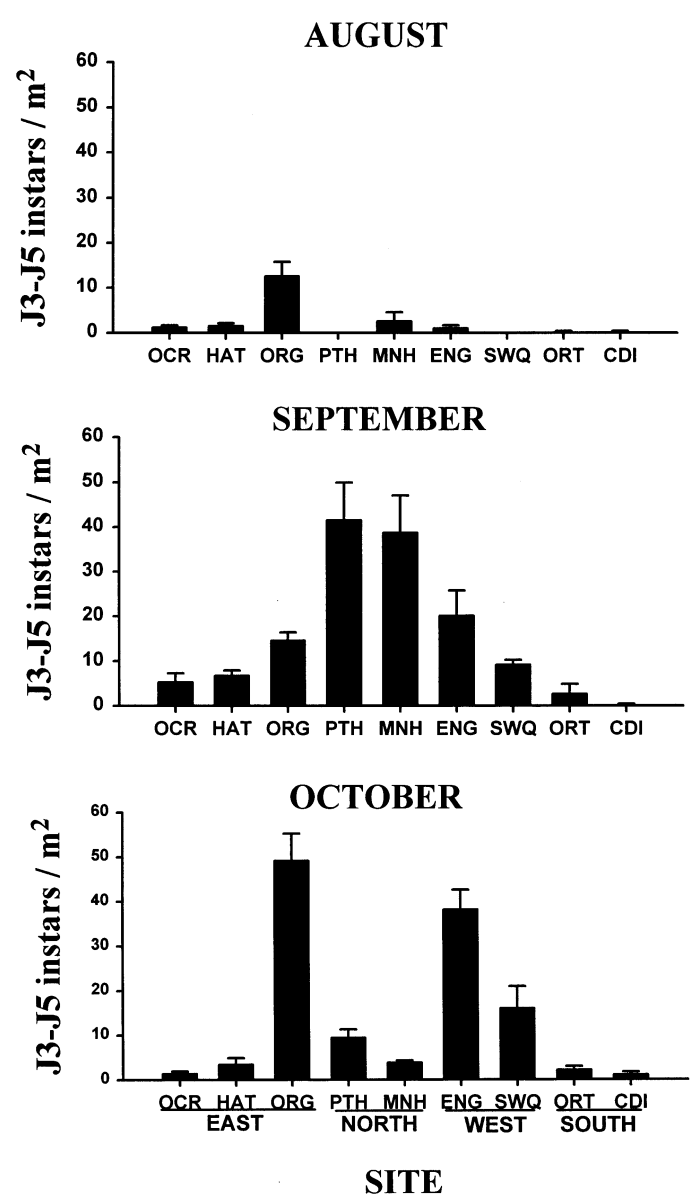

Fig. 4. Density of benthic juvenile instars 3 through 5 (J3-J5: early recruits) as a function of Month and Site. Juvenile densities were obtained from the habitat within each site and during a specific sampling period (Month) that contained the highest crab densities. Values are means $+1 \mathrm{SE}$. (Table 4 ) 
Table 4. Effects of Site (CISL, OCR, HAT, ORG, PTH, MNH, ENG, SWQ, ORT) and sampling Month (August, September, and October 1996) upon the mean numbers of (1) J1-J2 (log[x +1$]$-transformed) and (2) J3-J5 (square root-transformed) blue crab instars per $1.67 \mathrm{~m}^{2}$ (Figs. 3 \& 4)

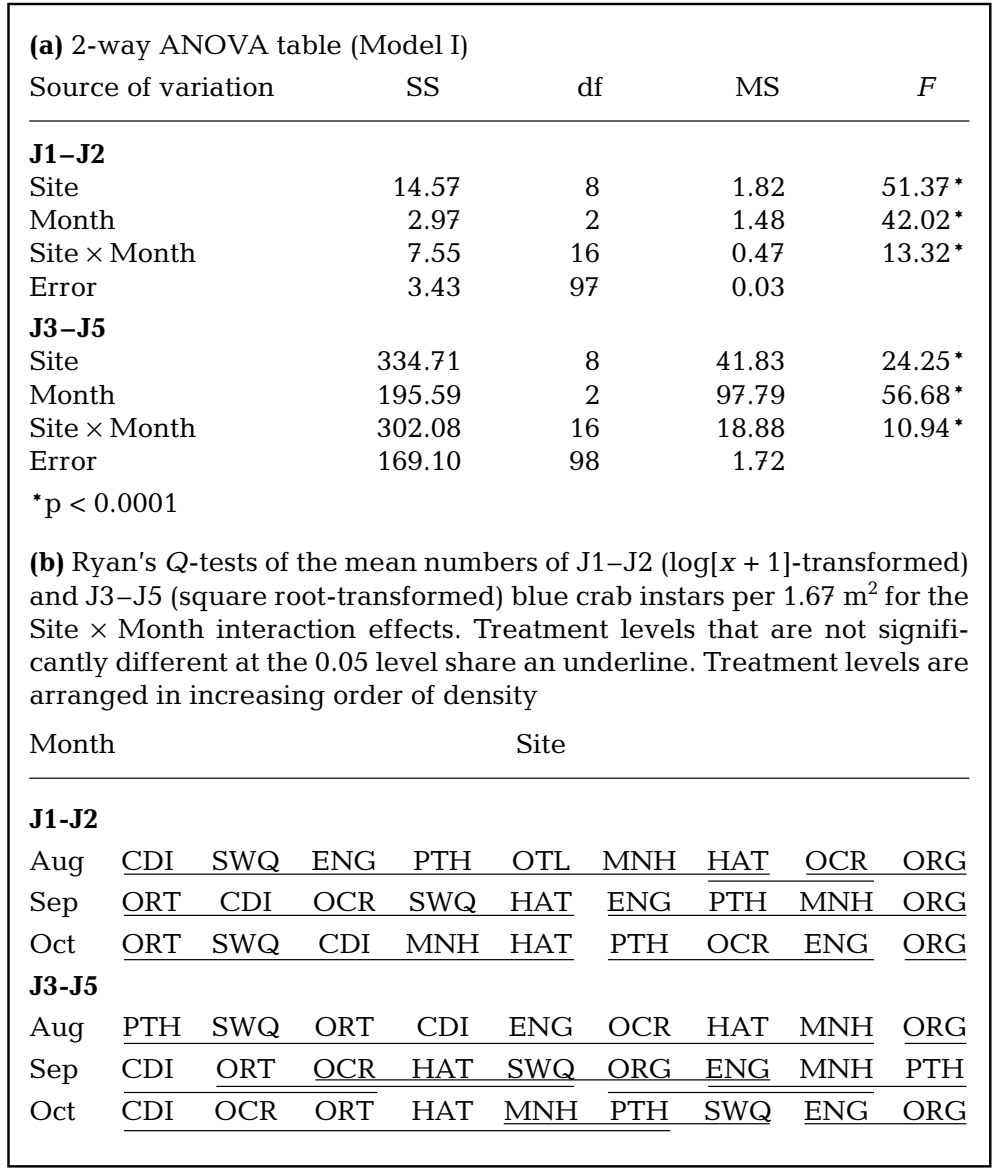

densities of both groups of instars were significantly higher in complex than unstructured benthic habitats (Table 5, Ryan's Q-test; Fig. 5). The Month main effect and the Month $\times$ Habitat type interaction effect were non-significant for both size classes (Table 5).

Comparisons of crab abundance between complex habitats within a site

Engelhard was the only site where SG and SDH co-occurred, which allowed us to make comparisons of crab size-specific habitat use without the confounding effects of different sampling sites. The mean density of blue crab settlers (J1-J2) was similar between SG and SDH, as well as between September and October (Fig. 6a, Table 6a). The Month $\times$ Habitat type interaction was non-significant (Table 6a). The density of early recruits (J3-J5) varied significantly between seagrass and shallow detrital habitats; however, a significant Month $\times$ Habitat interaction precluded contrasts across the main effects (Fig. 6b, Table 6a). In September, the densities of J3-J5 blue crabs did not differ between SG and SDH, whereas in October there were significantly more blue crabs in SG than SDH (Fig. 6b, Table 6b).
(Oriental, Cedar Island) consistently harbored the lowest densities of J3-J5 throughout the recruitment season, similar to the pattern observed for J1-J2 instars (compare Figs. $3 \& 4$ ).

The mean density of both $\mathrm{J} 1-\mathrm{J} 2$ and J3-J5 instars varied significantly according to Site and Month; however, a significant Site $\times$ Month interaction effect precluded contrasts across the main effects for both groups of instars (Table 4a). Specific differences in juvenile densities between Sites as a function of Month are outlined for both size classes in Table $4 \mathrm{~b}$.

\section{Habitat-specific abundance patterns}

\section{General habitat comparisons of crab abundance}

The densities of recent settlers $(\mathrm{J} 1-\mathrm{J} 2)$ and early juvenile recruits (J3-J5) were similar between complex benthic habitats (SG, SRV, SDH); however, the
Table 5. Effects of Month (September and October) and Habitat type (SG, SRV, SDH, UNST) on densities of J1-J2 $(\log [x+0.1]$ and J3-J5 $(\log [x+0.1])$ blue crab instars pooled over all sites except Cedar Island and Oriental (Fig. 5)

\begin{tabular}{|c|c|c|c|c|}
\hline \multicolumn{5}{|c|}{ 2-way ANOVA table (Model I) } \\
\hline Source of variation & SS & $\mathrm{df}$ & MS & $F$ \\
\hline \multicolumn{5}{|l|}{ J1-J2 } \\
\hline Month & 0.170 & 1 & 0.011 & $0.28 \mathrm{~ns}$ \\
\hline Habitat & 39.241 & 3 & 13.080 & $21.89^{*}$ \\
\hline Month $\times$ Habitat & 2.967 & 3 & 0.989 & $1.66 \mathrm{~ns}$ \\
\hline Error & 10.520 & 110 & 0.095 & \\
\hline \multicolumn{5}{|l|}{ J3-J5 } \\
\hline Month & 0.796 & 1 & 0.796 & $2.23 \mathrm{~ns}$ \\
\hline Habitat & 67.803 & 3 & 22.601 & $63.19^{*}$ \\
\hline Month $\times$ Habitat & 4.456 & 3 & 1.485 & $4.15 \mathrm{~ns}^{\mathrm{a}}$ \\
\hline Error & 39.343 & 110 & 0.357 & \\
\hline \multicolumn{5}{|c|}{$\begin{array}{l}\text { ns: } p>0.05,{ }^{*} p<0.001 \\
n s^{\mathrm{a}}: \mathrm{p}>0.001(\text { Cochran's } C \text {-test rejected homogeneous } \\
\quad \text { variances at } \mathrm{p}<0.001)\end{array}$} \\
\hline
\end{tabular}



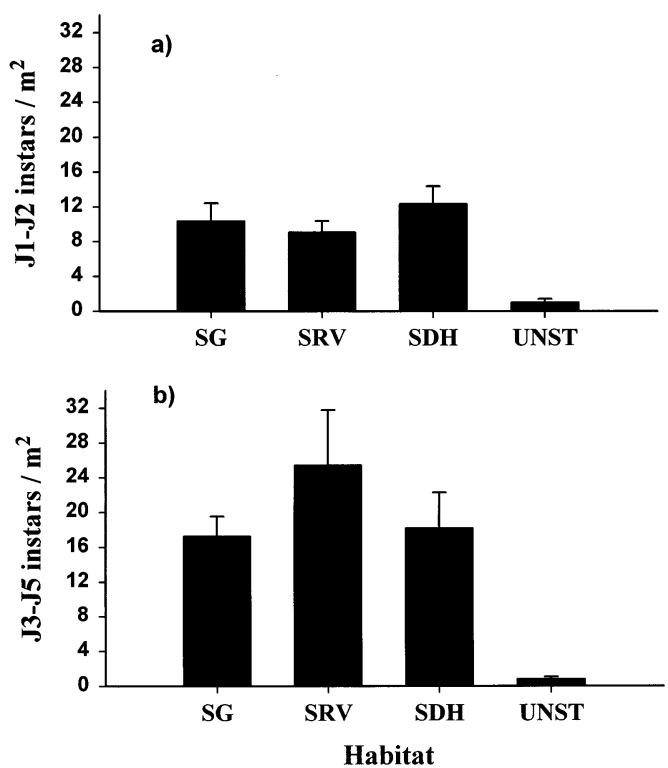

Fig. 5. Habitat-specific density of (a) J1-J2 and (b) J3-J5 instar stages of blue crabs. Crab densities for each Habitat type (seagrass [SG], submersed rooted vascular [SRV], shallow detrital habitat [SDH], unstructured [UNST]) were pooled across all sites (except Cedar Island and Oriental) and over the months of September and October. August was excluded because all habitat types were not sampled during that month. Cedar Island and Oriental were excluded due to extremely low densities of both juvenile size classes within these sites. Values are means + $1 \mathrm{SE}$ (Table 5)

Table 6. Effects of sampling Month (September and October 1996) and Habitat type (SG and SDH) upon the mean numbers of (1) J1-J2 and (2) J3-J5 blue crabs instars per $1.67 \mathrm{~m}^{2}$ at the Engelhard site (Fig. 6)

\begin{tabular}{|c|c|c|c|c|}
\hline \multicolumn{5}{|c|}{ (a) 2-way ANOVA table (Model I) } \\
\hline Source of variation & SS & $\mathrm{df}$ & MS & $F$ \\
\hline \multicolumn{5}{|l|}{ J1-J2 } \\
\hline Month & 184.26 & 1 & 184.26 & $1.15 \mathrm{~ns}$ \\
\hline Habitat & 73.15 & 1 & 73.15 & $0.46 \mathrm{~ns}$ \\
\hline Month $\times$ Habitat & 11.34 & 1 & 11.34 & $0.07 \mathrm{~ns}$ \\
\hline Error & 3201.75 & 20 & 160.08 & \\
\hline \multicolumn{5}{|l|}{ J3-J5 } \\
\hline Month & 585.09 & 1 & 585.09 & $2.19 \mathrm{~ns}$ \\
\hline Habitat & 6185.67 & 1 & 6185.67 & $23.15^{* *}$ \\
\hline Month $\times$ Habitat & 2511.26 & 1 & 2511.26 & $9.40^{*}$ \\
\hline Error & 5344.44 & 20 & 267.22 & \\
\hline \multicolumn{5}{|c|}{ ns: $\mathrm{p}>0.05,{ }^{*} \mathrm{p}<0.01,{ }^{* *} \mathrm{p}<0.001$} \\
\hline \multicolumn{5}{|c|}{$\begin{array}{l}\text { (b) Protected, lower-level ANOVA of the numbers of } \\
\text { J3-J5 blue crab instars for the Month } \times \text { Habitat type inter- } \\
\text { action effect. Treatment levels that are not significantly } \\
\text { different at the } 0.05 \text { level share an underline. Treatment } \\
\text { levels are arranged in increasing order of abundance }\end{array}$} \\
\hline Month & \multicolumn{4}{|c|}{ Habitat } \\
\hline September & \multicolumn{2}{|c|}{$\underline{\mathrm{SDH}}$} & \multicolumn{2}{|c|}{ SG } \\
\hline October & \multicolumn{2}{|c|}{$\underline{\mathrm{SDH}}$} & \multicolumn{2}{|c|}{$\underline{\mathrm{SG}}$} \\
\hline
\end{tabular}

Habitat complexity

\section{Seagrass}

Although densities of blue crab settlers (J1-J2) varied according to seagrass characteristics, there was no relationship between the density of either J3-J5 or J6-J9 instars and seagrass habitat characteristics (Tables 7 \& 8). Densities of blue crab settlers (J1-J2) were significantly different between Sites and Months; however, a significant Site $\times$ Month interaction effect precluded general contrasts across the main effects (Fig. 3, Table 7a). The interaction effect was due to monthly variations in the relative abundance of J1-J2 instars at Hatteras and Ocracoke Inlets; Oregon Inlet harbored the highest densities of settlers in all 3 mo (Fig. 3, Table 7b). Although densities of blue crab settlers (J1-J2) were not associated significantly with seagrass biomass or the number of shoots, there was a significant relationship between the density of settlers and increasing length of seagrass leaves (Table $7 \mathrm{a}$ ). A subsequent regression analysis of J1-J2 on mean seagrass length, however, was not significant for all sites within the Eastern region $(p=0.38)$ due to variation in blue crab settler density within Site and Month treat-
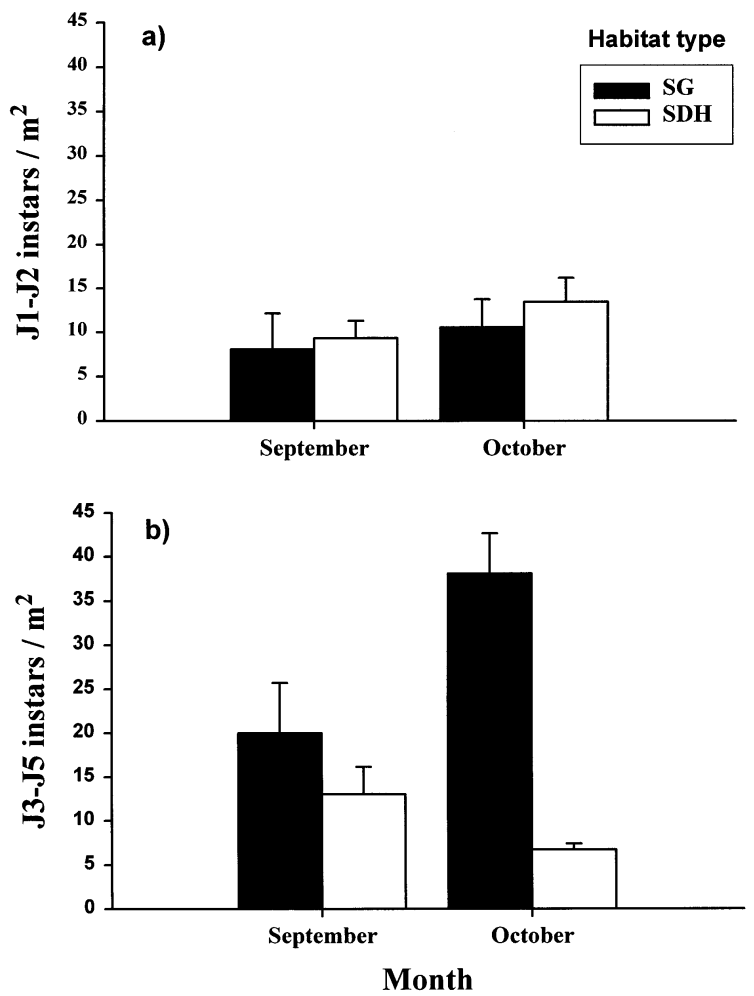

Fig. 6. Effects of sampling Month (September, October) and Habitat type (SG and SDH) on mean densities of (a) J1-J2 and (b) J3-J5 instar blue crabs within the Engelhard site. Values are means $+1 \mathrm{SE}$. (Table 6$)$ 
Table 7. Effects of seagrass habitat complexity (mean leaf length, biomass, number of short shoots), Site (ORG, HAT, OCR), and Month (August, September, October) on the mean numbers of (1) J1-J2 $(\log [x+1])$ and $(2) \mathrm{J} 3-\mathrm{J} 5(\log [x+1])$ blue crabs per $1.67 \mathrm{~m}^{2}$ within the Eastern region. (Fig. 7)

(a) 2-way reduced ANCOVA model table. Initially, all Factor $\times$ Covariate terms within both of the full models were non-significant (all $p>0.17$ ), therefore they were removed from the models and the models rerun. The results from the reduced models are shown below

\begin{tabular}{lcccc} 
Source of variation & SS & df & MS & $F$ \\
\hline J1-J2 & & & & \\
Site & 6.473 & 2 & 3.218 & $53.07^{* * *}$ \\
Month & 0.428 & 2 & 0.214 & $3.53^{*}$ \\
Site $\times$ Month & 1.011 & 4 & 0.252 & $4.17^{* *}$ \\
Length & 0.435 & 1 & 0.435 & $7.17^{*}$ \\
Biomass & 0.015 & 1 & 0.015 & $0.25 \mathrm{~ns}$ \\
Shoots & 0.199 & 1 & 0.199 & $1.98 \mathrm{~ns}$ \\
Error & 2.122 & 35 & 0.060 & \\
J3-J5 & & & & \\
Site & 5.259 & 2 & 2.629 & $30.42^{* * *}$ \\
Month & 0.990 & 2 & 0.459 & $5.73^{* *}$ \\
Site $\times$ Month & 1.310 & 4 & 0.327 & $3.79^{*}$ \\
Length & 0.002 & 1 & 0.002 & $0.03 \mathrm{~ns}$ \\
Biomass & 0.000 & 1 & 0.000 & $0.00 \mathrm{~ns}$ \\
Shoots & 0.056 & 1 & 0.056 & $0.65 \mathrm{~ns}$ \\
Error & 3.025 & 35 & 0.086 & \\
ns: $\mathrm{p}>0.05,{ }^{*} \mathrm{p}<0.05,{ }^{* *} \mathrm{p}<0.01,{ }^{* * *} \mathrm{p}<0.001$ &
\end{tabular}

(b) Ryan's $Q$-tests of the mean numbers of $\mathrm{J} 1-\mathrm{J} 2(\log [x+1])$ and J3-J5 $(\log [x+1]$-transformed) blue crab instars per $1.67 \mathrm{~m}^{2}$ for Site $\times$ Month interaction effect. Treatment levels that are not significantly different at the 0.05 level share an underline. Treatment levels are arranged in increasing order of density

Month Site

\begin{tabular}{llll}
\hline J1-J2 & & & \\
$\begin{array}{l}\text { August } \\
\text { September }\end{array}$ & $\underline{\text { HAT }}$ & $\underline{\text { OCR }}$ & ORG \\
October & $\underline{\text { HAT }}$ & $\underline{\text { OCR }}$ & $\underline{\text { ORG }}$ \\
J3-J5 & $\underline{\text { ORG }}$ & \\
$\begin{array}{l}\text { August } \\
\text { September }\end{array}$ & $\underline{\text { OCR }}$ & HAT & $\underline{\text { ORG }}$ \\
October & $\underline{\text { OCR }}$ & $\overline{\text { HAT }}$ & ORG \\
& $\underline{\text { OCR }}$ & $\underline{\text { ORG }}$
\end{tabular}

ment combinations. Thus, we examined the relationship between settler density and seagrass leaf length separately for each Eastern region site, since Site had a statistically stronger influence on J1-J2 instar densities than Month (Table $7 \mathrm{a}$ ). This approach yielded a significant relationship between $\mathrm{J} 1-\mathrm{J} 2$ blue crabs and seagrass leaf length at Ocracoke and Hatteras Inlets, and an increasing trend, but non-significant relationship at Oregon Inlet (Fig. 7).

In terms of the J3-J5 instars, there was a significant Site $\times$ Month interaction effect that prevented contrasting the means of the significant main factors (Fig. 4,
Table 8. Effects of seagrass habitat complexity (mean leaf length, biomass, number of short shoots), Site (ORG, HAT, OCR), and Month (August, September, October) on the mean numbers of J6-J9 instar blue crabs per $1.67 \mathrm{~m}^{2}$ within the Eastern region (Fig. 8)

Two-way repeated measures ANCOVA table. Initially, all Factor $\times$ Covariate terms within the full model were nonsignificant (all p > 0.07), therefore they were removed from the model and the model rerun. The results from the reduced model are shown below. Numdf and Dendf refer to numerator and denominator degrees of freedom respectively

\begin{tabular}{lccc} 
Source of variation & Numdf & Dendf & $F$ \\
\hline Site & 2 & 35 & $11.26^{*}$ \\
Month & 2 & 35 & $17.83^{*}$ \\
Site $\times$ Month & 4 & 35 & $1.62 \mathrm{~ns}$ \\
Length & 1 & 35 & $0.45 \mathrm{~ns}$ \\
Biomass & 1 & 35 & $0.65 \mathrm{~ns}$ \\
Shoots & 1 & 35 & $0.56 \mathrm{~ns}$ \\
ns: $\mathrm{p}>0.05,{ }^{*} \mathrm{p}<0.001$ & & & \\
\hline
\end{tabular}
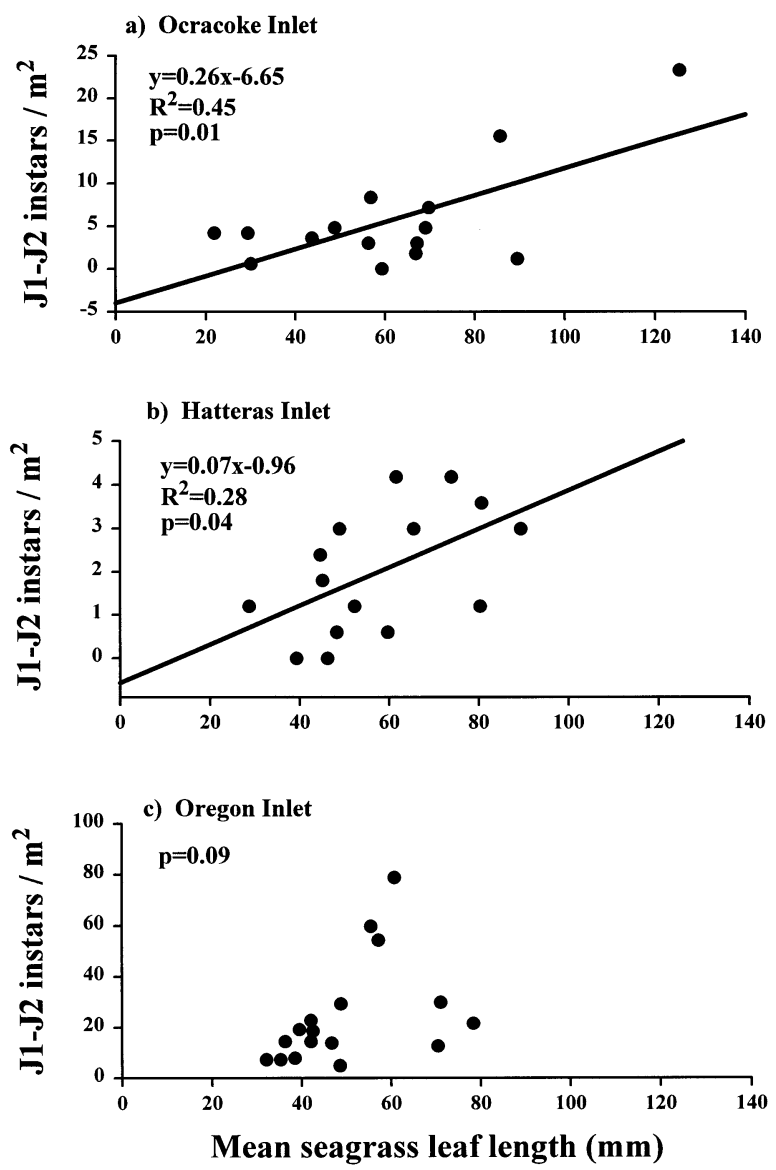

Fig. 7. Relationship between the density of J1-J2 blue crabs and mean seagrass leaf length within (a) Ocracoke Inlet (b) Hatteras Inlet and (c) Oregon Inlet. Each data point represents a single sample within August, September, or October. Where the model was not significant, a line was not fit to the data. Note the different scales on the $y$-axes. (Table 7) 


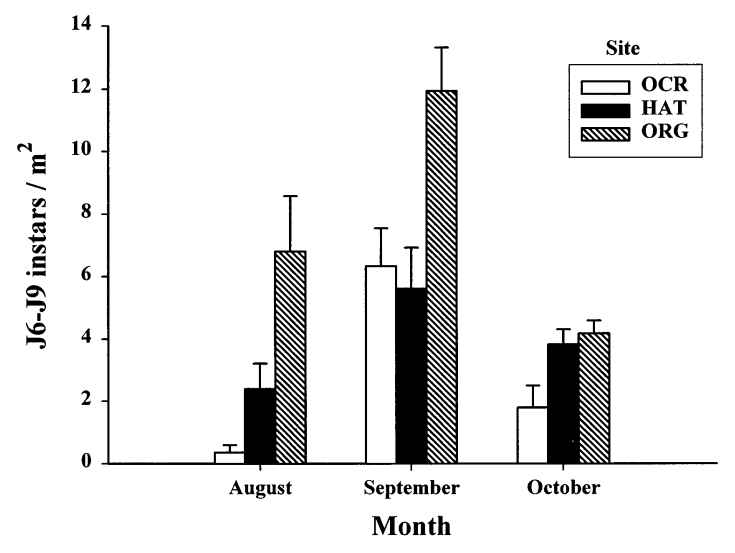

Fig. 8. Effects of sampling Month (August, September, October) and Site (OCR, HAT, ORG) on mean densities of J6-J9 instar blue crabs within the Eastern shore region. Values are means $+1 \mathrm{SE}$. (Table 8$)$

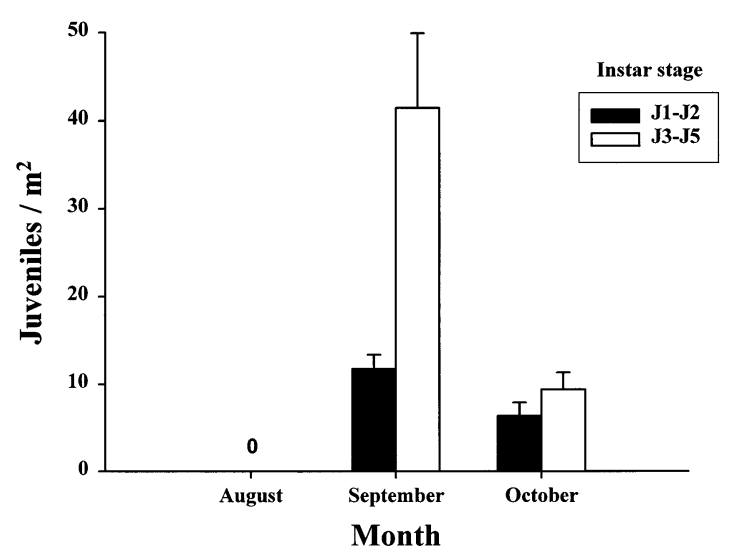

Fig. 9. Effect of Month (August, September, October) on densities of J1-J2 and J3-J5 blue crab instars within the SRV habitat at the Point Harbor site. Values are means $+1 \mathrm{SE}$

Table 7a). The significant interaction effect was due to similar densities of J3-J5 crabs among stations within the Eastern region in September, in contrast to patterns in August and October when densities at Oregon Inlet were significantly higher than those at Hatteras and Ocracoke Inlets (Fig. 4, Table 7b). J3-J5 blue crabs were not significantly influenced by seagrass characteristics (Table 7a).

J6-J9 instars varied as a function of Month and Site, with higher mean densities at Oregon Inlet as compared to the other 2 Eastern region sites, and higher densities in September compared to August and October (Fig. 8, Table 8; Ryan's $Q$ multiple comparisons tests). As with the early recruits, the densities of J6-J9 instars did not show a significant association with any of the seagrass characteristics that were quantified (Table 8). There was also a non-significant Site $\times$ Month interaction effect (Table 8).
$S R V$

Densities of J1-J2 instars within the SRV habitat at Point Harbor varied over Month (ANCOVA; $F=18.21$, $\mathrm{df}=2,14, \mathrm{p}=0.0001$ ), with highest densities in September, significantly lower densities in October, and zero crabs collected in August (Fig. 9; Ryan's $Q$ multiple comparisons tests). Blue crab settlers were not significantly influenced by SRV biomass (ANCOVA; $F=0.13, \mathrm{df}=1,14, \mathrm{p}=0.7241$ ). Similar to blue crab settlers, J3-J5 instars varied significantly by Month (ANCOVA $; F=119.56, \mathrm{df}=2,14, \mathrm{p}=0.0001$ ), with highest densities in September, significantly lower densities in October, and zero crabs collected in August (Fig. 9; Ryan's $Q$ multiple comparisons tests). There was no significant relationship between early recruits and SRV biomass $\left(\mathrm{ANCOVA}_{i} F=0.31\right.$, df $=$ $1,14, \mathrm{p}=0.5836$ ).

\section{$S D H$}

Densities of J1-J2 instars within the SDH habitat differed significantly by Month as well as Site, but a significant Site $\times$ Month interaction prevented contrasting the main effects (Fig. 10a, Table 9a). The interaction effect was due to higher densities of J1-J2 instars at
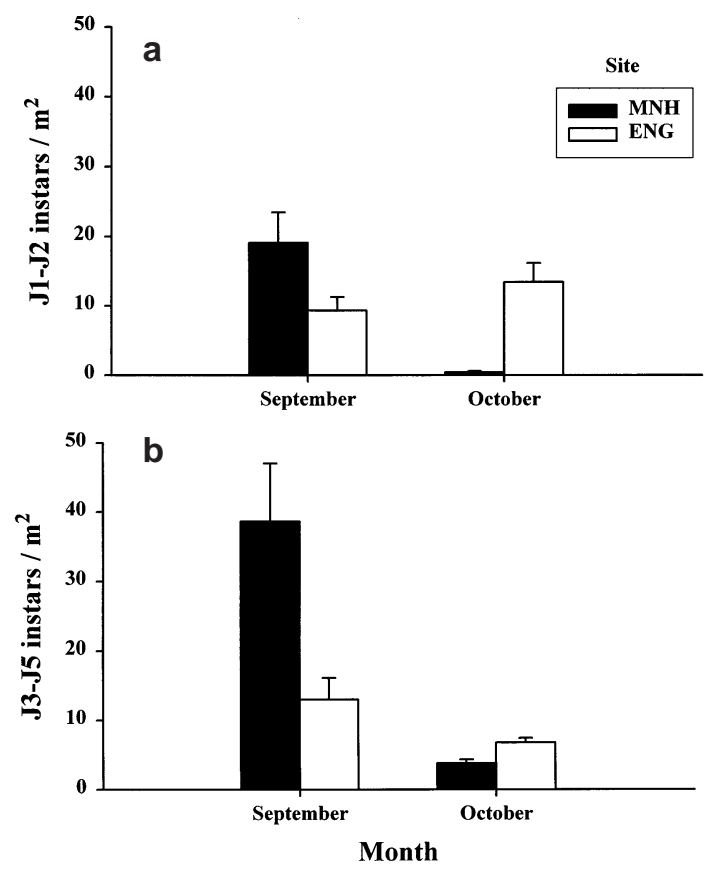

Fig. 10. Effects of Site (MNH, ENG) and Month (September, October) on the density of (a) J1-J2 and (b) J3-J5 instar blue crabs within shallow detrital habitat. Values are means $+1 \mathrm{SE}$. (Table 9) 
Manns Harbor than Engelhard in September, and higher densities at Engelhard than Manns Harbor in October (Table 9b). There was no significant relationship between J1-J2 density and SDH volume (Table 9a). The J3-J5 size class demonstrated very similar results to those of the settlers. Densities within SDH varied significantly with Month; however, examination of the means was prevented by a significant Site $\times$ Month interaction effect (Fig. 10b, Table 9a). The Site $\times$ Month interaction effect was due to similar densities of J3-J5 instars between Manns Harbor and Engelhard in September, and higher densities of crabs at Engelhard than Manns Harbor in October (Fig. 10b, Table 9b). There was no significant relationship between densities of J3-J5 instars and SDH volume (Table 9a).

Table 9. Effects of shallow detrital habitat complexity (SDH volume), Site (MNH, ENG), and Month (September, October) on the mean numbers of (1) J1-J2 $(\log [x+1])$ and (2) J3-J5 $(\log [x+1])$ blue crab instars per $1.67 \mathrm{~m}^{2}$ (Fig. 10)

(a) 2-way reduced ANCOVA table. Initially, all Factor $x$ Covariate terms within both of the full models were nonsignificant $(p>0.25)$, therefore they were removed from the model. The results from the reduced model are shown below

\begin{tabular}{lcrcc} 
Source of variation & SS & df & MS & $F$ \\
\hline J1-J2 & & & & \\
Site & 0.86 & 1 & 0.86 & $15.87^{*}$ \\
Month & 1.44 & 1 & 1.44 & $26.56^{* *}$ \\
Site $\times$ Month & 2.46 & 1 & 2.46 & $45.35^{* *}$ \\
SDH volume & 0.00 & 1 & 0.00 & $0.09 \mathrm{~ns}$ \\
Error & 0.92 & 17 & 0.05 & \\
J3-J5 & & & & \\
Site & 0.05 & 1 & 0.05 & $1.46 \mathrm{~ns}$ \\
Month & 1.56 & 1 & 1.56 & $38.84^{* *}$ \\
Site $\times$ Month & 0.58 & 1 & 0.58 & $14.59^{*}$ \\
SDH volume & 0.02 & 1 & 0.02 & $0.62 \mathrm{~ns}$ \\
Error & 0.68 & 17 & 0.04 & \\
ns: $p>0.05,{ }^{*} p<0.01,{ }^{* *} p<0.001$ & &
\end{tabular}

(b) Ryan's $Q$-tests of the mean numbers of (1) J1-J2 $(\log [x+1])$ and $(2) \mathrm{J} 3-\mathrm{J} 5(\log [x+1])$ blue crabs per $1.67 \mathrm{~m}^{2}$ for the Site $\times$ Month interaction effect. Treatment levels that are not significantly different at the 0.05 level share an underline. Treatment levels are arranged in increasing order of density

Month

Site

\section{J1-J2}

September

October

J3-J5

September

October

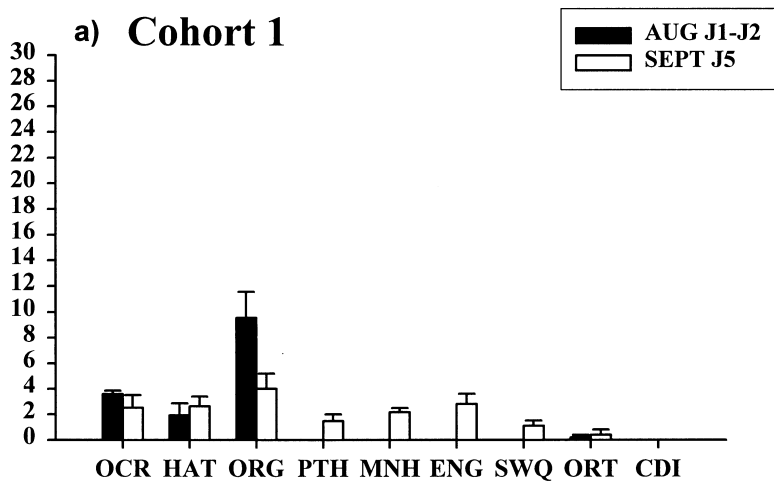

b) Cohort 2

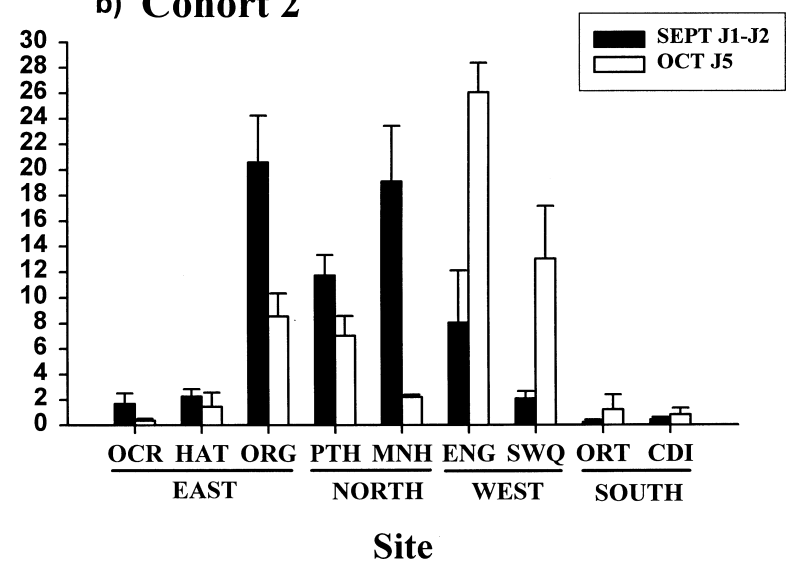

Fig. 11. Effect of sampling Site (OCR, HAT, ORG, PTH, MNH, ENG, SWQ, ORT, CDI) on the densities of J1-J2 and J5 instar blue crabs within (a) Cohort 1 (August J1-J2 and September J5) and (b) Cohort 2 (September J1-J2 and October J5). Juvenile densities were obtained from the habitat within each site and during a specific sampling Month that contained the highest crab densities. Values are means $+1 \mathrm{SE}$

\section{Settler-recruit relationships}

We did not try to measure continuous recruitment of juveniles throughout the season, but instead identified distinct cohorts which we were able to follow one month to the next, thus examining the relationship between settlers (J1-J2) and recruits (J5). One of the most striking patterns to emerge when examining spatial variation in the relationship between recent settlers and recruits (4 to $6 \mathrm{wk}$ post-settlement) was evidence of post-settlement, planktonic dispersal. For example, recent settlers for Cohort 1 were found nearly exclusively in seagrass beds along the soundside of the Outer Banks, yet (with the exception of Cedar Island) J5 instars were collected throughout the CAPES the following month (Fig. 11a). A similar pattern of substantially higher densities of J5 than J1-J2 instars was observed at the Western region (Engelhard, Swanquarter) for Cohort 2 (Fig. 11b). 


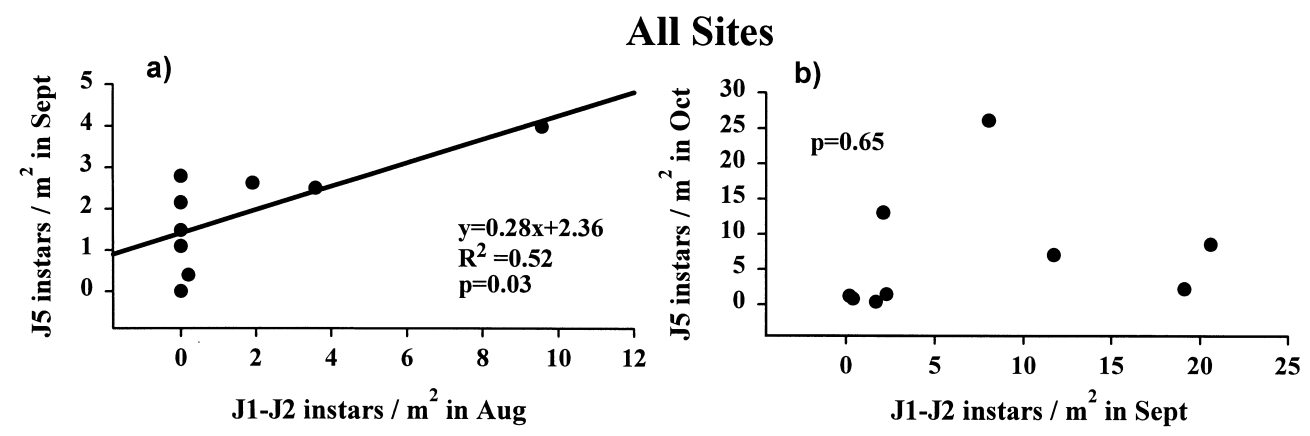

Sites with settler : recruit $>1$
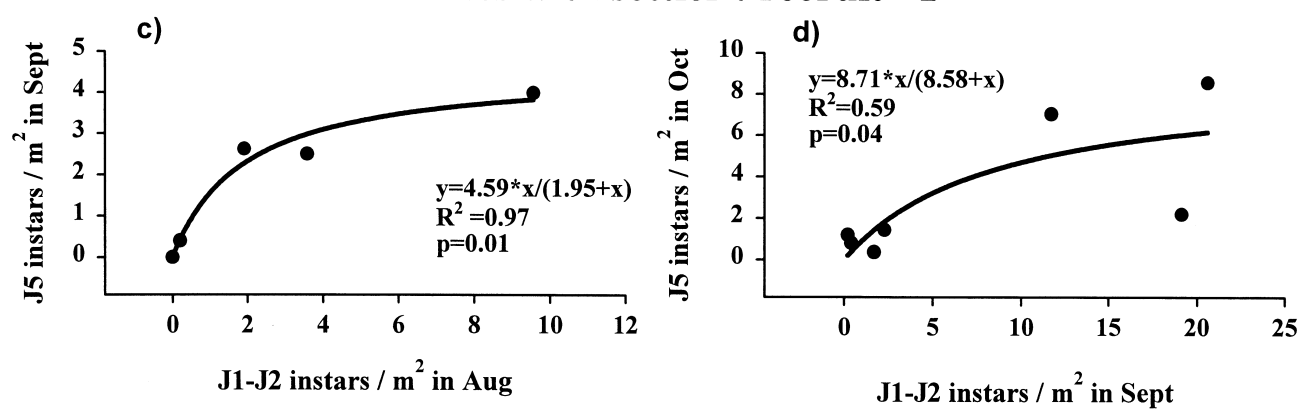

Fig. 12. Settler-recruit relationships for (a) Cohort 1 (August J1-J2 and September J5 instars), (b) Cohort 2 (September J1-J2 and October J5 instars), (c) Cohort 1 in which data points were removed for sites that contained fewer J1-J2 than J5 instars (i.e., settler:recruit <1), and (d) Cohort 2 in which data points were removed for sites that contained settler:recruit $<1$. Each data point represents the mean for each site from the habitat which contained the highest crab densities. Regression lines are the best fitting functions (see text). Where the model was not significant, a line was not fit to the data. Note the different scales on both axes

The settler (J1-J2)-recruit (J5) relationship was examined by regression analysis to assess the form of the relationship between these life history stages (Fig. 12). Analysis of the form of the relationship (Eq. 1) for Cohort 1 , with all sites included, indicated a linear relationship between August J1-J2 and September J5 with $\beta$ (0.34) significantly different from 1 and 2 , but not from 0 . Thus, the linear model was chosen to describe the form of the settler-recruit relationship for Cohort 1 (Fig. 12a). The analysis of Cohort 2 (September J1-J2 instars and October J5 instars), when all sites were included, yielded a $\beta$ value of 0.48 , which was not significantly different from 0 or 1 , suggesting a linear or hyperbolic relationship. We chose the simpler linear model, which demonstrated a non-significant relationship between J1-J2 instars in September and J5 instars in October (Fig. 12b). When sites that received substantial post-settlement immigration were eliminated from the regression analysis (i.e., removal of sites with ratio of settler:recruit $<1$ ) the form of the settler-recruit relationship for Cohort 1 was hyperbolic, with $\beta(0.93)$ significantly different from 0 and 2, but not from 1 (Fig. 12c). Similarly, when sites that received substantial post-settlement immigration were eliminated from the regression analysis for Cohort 2, the form of the relationship between September J1-J2 instars and October J5 instars was hyperbolic with $\beta$ (0.59) significantly different from 0 and 2, but not from 1 (Fig. 12d). The amount of variation in the densities of recruits that was explained by settler densities was greatly improved when sites with post-settlement immigration were removed from the analysis. For example, the amount of variation explained by the model for Cohort 1 increased from 0.52 to 0.97 (compare Fig. 12a,c). By removing sites with post-settlement immigration, the settlerrecruit relationship within Cohort 2 shifted from a nonsignificant relationship to a significant relationship that explained a relatively high amount of variation $\left(R^{2}=\right.$ 0.59) (compare Fig. 12b,d). Our assessment of the settlerrecruit relationship varied depending upon the scale of observation. If examined on a regional scale with all sites included, we conclude that the relationship between these life history stages is density-independent, whereas if the influence of postsettlement planktonic immigration is removed, the relationship appears density-dependent. Thus, our interpretation of population regulation is largely scale-dependent.

\section{DISCUSSION}

Through large-scale field sampling using standardized techniques, we demonstrated that recruitment of early juvenile blue crabs was jointly influenced by 
location within the CAPES, sampling month within the recruitment season (which was coupled with the passage of tropical cyclones; Fig. 2), and the availability of complex nursery habitats. Our results suggest that the Eastern region, particularly Oregon Inlet, serves as a consistent initial recruitment site for early juvenile crabs for the entire CAPES, due to a favorable combination of close proximity to sources of postlarvae (inlets) and the presence of expansive seagrass beds. Nevertheless, the nursery capacity of the entire sound system may also expand during the passage of tropical cyclones due to a combination of enhanced postlarval delivery (Eggleston et al. unpubl.), and post-settlement, planktonic dispersal to areas that do not normally receive settlers and early juveniles (this study), as well as the presence of alternative nursery habitats (SDH and SRV) located at inshore areas (this study). The ecological function of these alternative nursery habitats in terms of crab growth and survival, however, is unknown. Overall, distribution of early juvenile blue crabs within the CAPES appears to be largely determined by physical transport processes.

\section{Spatiotemporal variation in abundance of recent settlers and early recruits}

The general findings regarding the distribution and abundance of recent blue crab settlers and early recruits are: (1) the Eastern region, particularly Oregon Inlet, consistently received moderate to high recruitment of blue crabs; (2) Northern and Western regions were characterized by variable recruitment; and (3) the Southern region consistently harbored low abundances of settlers and recruits. These patterns suggest that recruitment is dependent upon the distance and orientation of an area from oceanic sources of postlarvae, as well as the time period within the recruitment season.

The overall intensity of blue crab recruitment throughout the season could be a reflection of the availability of megalopae in offshore waters and winddriven forcing events. The general patterns of early juvenile abundance closely paralleled those from a study of spatiotemporal variation in postlarval settlement conducted during the same recruitment season (Eggleston et al. unpubl.). For example, both postlarval supply and early juvenile abundance were consistently high throughout the recruitment season at Eastern region stations, whereas high postlarval settlement and early juvenile abundance at inshore locations were dependent upon the passage of tropical cyclones (Eggleston et al. unpubl., this study).

The distribution of juvenile recruitment, as well as the frequency of tropical cyclones (Fig. 2), changed dramatically over the three months that crabs were sampled. The spatial distribution of juveniles throughout the CAPES increased in September and October (which contained tropical cyclones), which parallels the extension of postlarval settlement to inshore locations associated with tropical cyclone events (Eggleston et al. unpubl.). Contrary to our expectations, early juvenile densities within the Northern and Western regions were moderate to high within alternative, structurally complex habitats such as shallow detritus and submersed rooted vascular plants. The impact of storm events varied between months; 3 hurricanes occurred within a $2 \mathrm{wk}$ period prior to the September sampling period, whereas tropical storm 'Josephine' was the only major environmental forcing event, which occurred between the September and October sampling periods (Fig. 2; see Eggleston et al. unpubl. for details). The greater number and intensity of storms in September compared to October could explain why higher densities of juveniles were found throughout the Northern and Western regions in September, as compared to October, when more individuals were within the Western region. Since a decrease in turbulence evokes a behavioral response by megalopae of descent in the water column (Welch et al. 1999), we would not expect increased settlement along the sound side of the Outer Banks during storm events, but rather that megalopae would continue swimming and be transported further into the CAPES with the stormassociated water mass (Eggleston et al. unpubl.). The propensity for megalopae to remain in the water column during a strong influx of oceanic water associated with the passage of tropical cyclones may explain why we did not see higher juvenile recruitment to the Eastern region during months with a high frequency of tropical cyclones.

Previous studies have documented the effects of storm-driven transport on (1) larval supply of fishes and crustaceans to shallow nursery habitats (Goodrich et al. 1989, Shenker et al. 1993, Eggleston et al. 1998b); (2) the redistribution of juveniles within an estuarine system (Dorf \& Powell 1997); and (3) fluctuations in year class strength (Matlock 1987). Results from this study add to this body of information, giving a broad spatial view of how tropical cyclones can potentially influence spatiotemporal variability in recruitment patterns by increasing juvenile abundance in alternative estuarine nursery habitats in a shallow, lagoonal estuary.

\section{Habitat-specific abundance patterns}

The results from this study demonstrate that alternative, structurally complex habitats such as shallow 
detritus and the SRV species Myriophyllum spicatum harbor densities of early juvenile blue crabs that are similar to those in seagrass. Densities of both recent settlers and early recruit blue crabs were similar in all complex habitats (SRV, SDH, SG), and were significantly higher than crab densities observed in unstructured bottom. These 3 complex habitat types vary greatly in their general morphology and complexity, as well as the environmental conditions (e.g., salinity, energy regime) within which they occur. For example, seagrass is characteristically long and thin and, in North Carolina, was located in high salinity and moderate wave energy areas. SRV is tall and branching and was found in low salinity, low wave energy regimes. SDH is a low relief habitat with intricate crevices, and was associated with moderate salinity and a high energy regime along the western shore of Pamlico Sound. Although J1-J2 crab abundances were similar across alternative, structurally complex habitats, demographic rates may be habitat-specific. Therefore, further studies are needed to examine growth, survival, and dispersal rates within SRV and SDH to assess their nursery value in comparison with seagrass areas.

When densities of early juvenile blue crabs were compared between complex habitats within a single site, habitat use by juvenile blue crabs was size-specific. For example, although densities of J1-J2 instars in $\mathrm{SDH}$ were similar to those found in seagrass, the densities of J3-J5 were significantly higher in seagrass relative to $\mathrm{SDH}$. This habitat- and size-specific change in abundance may have resulted from a variety of ecological processes including size- and habitat-specific predation-induced mortality or emigration. Similar size-specific patterns of habitat use were recognized with early juvenile blue crabs within the Chesapeake Bay, whereby a lack of settlers was found in marsh creek habitats in comparison to a peak in settlement in nearby seagrass beds, followed by a subsequent peak of later juveniles within marsh creek areas (Orth \& van Montfrans 1987). The ontogenetic habitat shift by early juvenile blue crabs from seagrass to marsh creek may have been due to relatively high predation on early setters within the marsh creek habitat or selective settlement into seagrass, followed by immigration into marsh creek areas at a larger size (Orth \& van Montfrans 1987). The mechanisms underlying the size-specific patterns of early juvenile habitat use within seagrass and shallow detritus within the CAPES observed in this study await further testing.

The density of numerous species of marine organisms increases with increasing habitat complexity (reviews in Heck \& Orth 1980, Orth et al. 1984). This relationship has been attributed to reduced foraging success of predators with increasing habitat complex- ity (with a threshold level of complexity necessary before foraging success is significantly reduced) (review in Orth 1992), as well as micro-habitat preferences by prey organisms (Bell \& Westoby 1986). We therefore hypothesized that juvenile abundance would be positively correlated with measures of habitat complexity for each of the 3 structurally complex habitats (SG, SRV, SDH) quantified in this study. This was not the case for SRV biomass or SDH displacement volume, and only 1 of 3 measures of seagrass habitat complexity was positively correlated with crab density. A possible explanation for this lack of association with habitat complexity is that the SDH and SRV habitats were extremely intricate, providing an excess of refuge crevices and substantial structure inhibiting predatory capture.

The positive relationship between densities of J1-J2 crabs and the height of seagrass leaves may be attributed to the alteration of currents over seagrass beds as well as the increase in surface area of structure within the upper water column. The scale, geometry, and density of protruding structures determine the hydrodynamic properties of near-bed flows (Eckman 1983). Longer seagrass leaf length could decrease current speeds, thereby causing increased passive deposition of postlarvae or active site selection based on smallscale changes in flow (Eckman 1979, Peterson et al. 1984). Longer leaf length could provide more surface area in the water column for postlarval crabs to cling to, as well as increasing the complexity of the habitat, thus potentially decreasing predation risk (Orth 1992). The reasons for the lack of correlation between juvenile densities and seagrass biomass and number of shoots for all 3 size classes remain uncertain.

\section{Settler-recruit relationships and post-settlement, planktonic dispersal}

Spatial variation in settler-recruit densities for 2 separate cohorts of blue crabs during the 1996 recruitment season provided strong evidence that post-settlement juveniles were dispersing throughout the CAPES, most likely by planktonic transport. Furthermore, recent field mark-recapture and laboratory flume experiments have demonstrated conclusively that early juvenile blue crabs disperse planktonically and that this activity is due to an active behavioral response (Blackmon \& Eggleston in press). It seems unlikely that early juveniles (J1-J5) dispersed from seagrass beds in the Eastern region to the Northern and Western regions of the CAPES $(\sim 50 \mathrm{~km})$, by crawling along unstructured bottom, since (1) predation rates for this size class are significantly higher within unstructured bottom than vegetated habitats (Pile et al. 1996), (2) very few indi- 
viduals are found within unstructured areas (this study, Orth \& van Montfrans 1987, Pile et al. 1996), and (3) the speed necessary for juvenile crabs to cover $50 \mathrm{~km}$ in $30 \mathrm{~d}\left(1.66 \mathrm{~km} \mathrm{~d}^{-1}\right)$ is far greater than estimated average rates of movement for adult blue crabs tagged in Pamlico Sound $\left(0.25 \mathrm{~km} \mathrm{~d}^{-1}\right.$; Shirley \& Wolcott 1991). Furthermore, densities of J3-J5 instars on passive collectors within the Northern and Western regions were higher following storm events, as well as during strong south and southeasterly winds, than compared to the rest of the recruitment season (D.B.E. \& L.L.E. unpubl. data), which suggests that J3-J5 instars disperse planktonically, particularly during storm events.

In the CAPES system, planktonic redistribution of juveniles appears to generally occur in an east to west direction, with early juveniles within the Eastern region emigrating to Western and Northern regions. This trend was most apparent with Cohort 1, where the only source of J1-J2 instar juveniles that would subsequently be collected as J5 individuals in Northern and Western regions occurred within the Eastern region. A similar transport scenario is suggested by Cohort 2, in which the highest densities of settlers (J1-J2) were found at Oregon Inlet, making these individuals the likely source of juvenile dispersers showing up as very high densities of J5 instars within the Western region. These patterns of redistribution suggest that, in addition to serving as a local source of juvenile blue crabs, seagrass beds along the sound-side of the Outer Banks may serve as a type of 'landing strip' for settling postlarvae, and as a regional 'source' area for post-settlement crabs that disperse via the water column.

Although our data demonstrates that post-settlement, planktonic dispersal is associated with storm events, the planktonic transport of early juveniles may be a consistent transport mechanism occurring during a variety of environmental scenarios, whereby juveniles disperse from the Eastern to the Northern and Western regions of the CAPES. Early juveniles may be exhibiting behavioral responses such as increased swimming to differing turbulence levels, salinity, temperature, time of day, or other factors which would enhance planktonic dispersal (Blackmon \& Eggleston in press). Around the inlets, tidal forcing as well as wind-driven currents likely serve as transport mechanisms, while wind-driven currents likely serve as the primary means of transport further within the estuary where tidal transport is absent. Post-settlement, planktonic dispersion may be enhanced during storm events since the influx of oceanic water could serve as a transport mechanism to inshore locations.

Pile et al. (1996) hinted at the possibility of storminduced, planktonic transport of early juvenile blue crabs. They observed an increase in juvenile crabs (greater than the first instar) at a leeward site after Hurricane 'Danielle' passed close to the Chesapeake Bay, suggesting that these early benthic stages of blue crabs are either transported to, or select a low-energy habitat during storm events (Pile et al. 1996). In a second example of this post-settlement dispersal phenomenon, a mass escape of stained juvenile blue crabs during a storm event in the Chesapeake Bay, and their subsequent retrieval on artificial settlement substrates $10 \mathrm{~km}$ up-estuary (Perkins-Visser et al. 1996), also suggest that early juvenile blue crabs exhibit long-distance, water-column dispersal.

The form of the relationship between settlers and recruits over the broad scale of the CAPES system and for 2 individual cohorts was altered greatly by the influence of post-settlement, planktonic dispersal. When sites exhibiting high post-settlement immigration were removed from the analysis of the relationship between settlers and recruits, the settler-recruit relationship appeared density-dependent for 2 individual cohorts, in contrast to a linear or no relationship when post-settlement dispersal was not accounted for. Although the apparent density-dependent relationship may be driven by 1 to 2 data points at high densities of J1-J2 (Fig. 12c,d), there is other evidence for density-dependence among juvenile blue crabs (Pile et al. 1996, Eggleston 1998, Kahn et al. 1998). For example, Pile et al. (1996) identified a density-dependent (hyperbolic) settler(J1)-recruit(J5) relationship in Chesapeake Bay and suggested that emigration was the mechanism underlying this relationship since densitydependent predation was not detected. Kahn et al. (1998) identified a similar density-dependent relationship among blue crab young-of-the-year (YOY; $<60 \mathrm{~mm}$ ) and recruits (60 to $120 \mathrm{~mm}$ ); however, they concluded that emigration was not a plausible source of the density-dependence due to the large scale of their study. Inter-cohort cannibalism has a strong influence in regulating juvenile blue crab dynamics (Dittel et al. 1995, Hines \& Ruiz 1995, Moksnes et al. 1997), and thus could be the driving force underlying densitydependent emigration as well as predation. Longdistance post-settlement dispersal could act as an additional mechanism enhancing the density-dependent relationship between settlers and recruits. This scenario would be expected within the Eastern region since it appears that the supply of juvenile planktonic dispersers are originating from this area. Within the Northern and Western regions, post-settlement dispersal could have the opposite effect, masking a densitydependent settler-recruit relationship due to the large abundance of recruits, leading to the incorrect assumption that the population was highly dependent upon recruitment of J1-J2 crabs. Recent work demonstrates that dispersal of marine and stream benthos 
involves more than initial colonization (recruitment) of substrate, and that this secondary planktonic dispersal may strongly influence local population and community dynamics (review by Palmer et al. 1996). The role of dispersal has often been ignored or minimized in ecological studies, thus its impact on local population dynamics is most likely underestimated (Palmer et al. 1996).

\section{CONCLUSIONS}

We propose a conceptual model in which, in the absence of tropical cyclones, seagrass beds behind the Outer Banks of North Carolina, USA serve as a type of 'landing strip' during the recruitment season, where blue crabs settle as megalopae and then are potentially transported via the water column as early juveniles, or disperse on the bottom as later-stage juveniles. Conversely, increased water levels associated with the passage of tropical cyclones may occasionally deliver postlarvae directly to alternative nursery habitats along the western shore of Pamlico Sound, as well as the mouth of Albemarle Sound (Eggleston et al. unpubl.). Whether or not these alternative habitats act as episodic 'source' areas or conversely as 'sinks' due to disproportionately high post-settlement mortality remains unknown. More extensive research is needed to tease apart the relative influence of pre- and post-settlement processes, as well as the role of various alternative habitats, in the production of juvenile blue crabs within the Croatan-Albemarle-Pamlico Estuarine System in North Carolina.

By taking a large-scale approach to examining recruitment dynamics, we identified how our interpretation of blue crab population dynamics can vary substantially depending upon the scale of study. The broad spatial scale of examination allowed us to identify post-settlement, planktonic dispersal of the blue crab within the CAPES. This finding highlights the importance of dispersal, not only in determining initial colonization, but also in post-settlement redistribution, and further stresses the connectedness of sub-populations within marine systems. The form of the relationship between different life history stages varied in this study depending upon the scale of examination, suggesting that our interpretation of population regulation is largely scale-dependent. The broad spatial coverage of sampling illustrated that juvenile blue crab distribution patterns within the CAPES depended largely on physical transport processes, and thus, the climatic events occurring during the recruitment season. High juvenile blue crab abundance within multiple, complex benthic habitats suggests that juveniles exhibit behavioral plasticity in their use of a variety of benthic habitats. Overall, the results from this study highlight the need to examine recruitment processes over broad spatial scales to obtain a better understanding of recruitment dynamics of marine invertebrates with open populations.

Acknowledgements. We would like to thank W. Bost, D. Blackmon, S. Brooke, C. Dahlgren, W. Elis, J. Humphrey, T. Kellison, S. Norris, and S. Ratchford for their herculean efforts with field work and sample processing. Drafts of the manuscript benefited from helpful comments by C. H. Peterson and D. L. Wolcott. We also thank J. van Montfrans and M. S. Fonseca for input on sampling methods. This research was financially supported by North Carolina Sea Grant (NA46RG0087), the South Eastern Regional Vision of Education, the National Science Foundation (OCE 97-34472), the Z. Smith Reynolds Foundation, and North Carolina State University.

\section{LITERATURE CITED}

Able KW, Heck KL, Fahay MP, Roman CT (1988) Use of saltmarsh peat reefs by small juvenile lobsters on Cape Cod, Massachusetts. Estuaries 11:83-86

Bell JD, Westoby M (1986) Abundance of macrofauna in dense seagrass is due to habitat preference, not predation. Oecologia 68:205-209

Blackmon DC, Eggleston DB (in press) Factors influencing planktonic, post-settlement dispersal of early juvenile blue crabs. J Exp Mar Biol Ecol

Booth DJ, Brosnan DM (1995) The role of recruitment dynamics in rocky shore and coral reef fish communities. Adv Ecol Res 26:309-385

Connell JH (1985) The consequences of variation in initial settlement vs. post-settlement mortality in rocky intertidal communities. J Exp Mar Biol Ecol 93:11-45

Dittel A, Hines A, Ruiz G, Ruffin K (1995) Effects of shallowwater refuge on behaviour and density-dependent mortality of juvenile blue crabs in Chesapeake Bay. Bull Mar Sci 57:902-916

Doherty P, Fowler P (1994) An empirical test of recruitment limitation in a coral reef fish. Science 263:935-939

Dorf BA, Powell JC (1997) Distribution, abundance, and habitat characteristics of juvenile tautog (Tautoga onitis, Family Labridae) in Narragansett Bay, Rhode Island, 1988-1992. Estuaries 20:589-600

Eckman JE (1979) Small-scale patterns and processes in a soft-substratum, intertidal community. J Mar Res 37: $437-457$

Eckman JE (1983) Hydrodynamic processes affecting benthic recruitment. Limnol Oceanogr 28:241-257

Eggleston DB (1995) Recruitment in Nassau grouper Epinephelus striatus: post-settlement abundance, microhabitat features, and ontogenetic habitat shifts. Mar Ecol Prog Ser 124:9-22

Eggleston DB (1998) Population dynamics of the blue crab in North Carolina: statistical analyses of fisheries survey data. Final report for Contract M-6053 to the NC Department of Environmental Health and Natural Resources, Division of Marine Fisheries

Eggleston DB, Armstrong D (1995) Pre- and post-settlement determinants of estuarine Dungeness crab recruitment. Ecol Monogr 65:193-216

Eggleston DB, Etherington LL, Elis WE (1998a) Organism 
response to habitat patchiness: species and habitatdependent recruitment of decapod crustaceans. J Exp Mar Biol Ecol 223:111-132

Eggleston DB, Lipcius RN, Marshall LS Jr, Ratchford SG (1998b) Spatiotemporal variation in postlarval recruitment of the Caribbean spiny lobster in the central Bahamas: lunar and seasonal periodicity, spatial coherence, and wind forcing. Mar Ecol Prog Ser 174:33-49

Eggleston DB, Elis WE, Etherington LL, Dahlgren CP, Posey MH (1999) Organism response to habitat fragmentation and diversity: habitat colonization by estuarine macrofauna. J Exp Mar Biol Ecol 236:107-132

Epifanio CE, Valenti CC, Pembroke AE (1984) Dispersal and recruitment of blue crab larvae in Delaware Bay, USA Estuar Coast Shelf Sci 18:1-12

Epifanio CE, Lobanoff MA, Connaughton VP, Welch JM (1994) Growth and development of Atlantic mud crab larvae fed natural zooplankton prey. J Exp Mar Biol Ecol 180: 165-174

Everett RA, Ruiz GM (1993) Coarse woody debris as a refuge from predation in aquatic communities. Oecologia 93: 475-486

Ferguson RL, Wood LL (1994) Rooted vascular beds in the Albemarle-Pamlico estuarine system. Albemarle Pamlico Estuarine Study, Raleigh, NC, Report No. 94-02

Fernandez M, Iribarne O, Armstrong D (1993) Habitat selection by young-of-the-year Dungeness crab Cancer magister and predation risk in intertidal habitats. Mar Ecol Prog Ser 92:171-177

Gaines SD, Bertness MD (1992) Dispersal of juveniles and variable recruitment in sessile marine species. Nature 360: $579-580$

Gaines SD, Brown S, Roughgarden J (1985) Spatial variation in larval concentrations as a cause of spatial variation in settlement for the barnacle, Balanus glandula. Oecologia 67:267-272

Goodrich DM, van Montfrans J, Orth RJ (1989) Blue crab megalopal influx to Chesapeake Bay: evidence for a winddriven mechanism. Estuar Coast Shelf Sci 29:247-260

Heck KL, Orth RJ (1980) Seagrass habitats: the roles of habitat complexity, competition and predation in structuring associated fish and motile macroinvertebrate assemblages. In: Kennedy VS (ed) Estuarine perspectives. Academic Press, Inc, New York, p 449-464

Heck KL, Thoman TA (1981) Experiments on predator-prey interactions in vegetated aquatic habitats. J Exp Mar Biol Ecol 53:125-134

Hines AH, Ruiz GM (1995) Temporal variation in juvenile blue crab mortality: nearshore shallows and cannibalism in Chesapeake Bay. Bull Mar Sci 57:884-901

Kahn DM, Cole RW, Michels SF, Whitmore WH (1998) Development of life-stage-specific indices of relative abundance and stock-recruit relationships for the Delaware Bay blue crab stock. J Shellfish Res 17:529-541

Lipcius RN, Hines AH (1986) Variable functional responses of a marine predator in dissimilar homogeneous microhabitats. Ecology 67:1361-1371

Lipcius RN, Stockhausen WT, Eggleston DB, Marshall LS Jr, Hickey B (1997) Hydrodynamic decoupling of recruitment, habitat quality and adult abundance in the Caribbean spiny lobster: source-sink dynamics? Mar Freshw Res 48:807-815

Matlock GC (1987) The role of hurricanes in determining year-class strength of red drum. Contrib Mar Sci 30:39-47

Mense DJ, Posey MH, West T, Kinchloe K (1995) Settlement of brachyuran postlarvae along the North Carolina Coast. Bull Mar Sci 57:793-806
Millikin MR, Williams AB (1980) Synopsis of biological data on the blue crab, Callinectes sapidus Rathbun. NOAA Tech Rep NMFS 1:1-39

Moksnes PO, Lipcius RN, Pihl L, van Montfrans J (1997) Cannibal-prey dynamics in young juveniles and postlarvae of the blue crab. J Exp Mar Biol Ecol 215:157-187

Olafsson EB, Peterson CH, Ambrose WG Jr (1994) Does recruitment limitation structure populations and communities of macro-invertebrates in marine soft sediments: the relative significance of pre- and post-settlement processes. Oceanogr Mar Biol Annu Rev 32:65-109

Olmi EJ III (1994) Vertical migration of blue crab Callinectes sapidus megalopae: implications for transport in estuaries. Mar Ecol Prog Ser 113:39-54

Orth RJ (1992) A perspective on plant-animal interactions in seagrasses: physical and biological determinants influencing plant and animal abundance. In: John DM, Hawkins SJ, Price JH (eds) Plant-animal interactions in the marine benthos. The Systematics Association, Vol 46. Clarendon Press, Oxford, p 147-164

Orth RJ, van Montfrans J (1987) Utilization of a seagrass meadow and tidal marsh creek by blue crabs Callinectes sapidus. I. Seasonal and annual variations in abundance with emphasis on post-settlement juveniles. Mar Ecol Prog Ser 41:283-294

Orth RJ, Heck KL, van Montfrans J (1984) Faunal communities in seagrass beds: a review of the influence of plant structure and prey characteristics on predator-prey relationships. Estuaries 7:339-350

Palmer MA, Allan JD, Butman CA (1996) Dispersal as a regional process affecting the local dynamics of marine and stream invertebrates. Trends Ecol Evol 11:322-326

Perkins-Visser E, Wolcott TG, Wolcott DL (1996) Nursery role of seagrass beds: enhanced growth of juvenile blue crabs (Callinectes sapidus Rathbun). J Exp Mar Biol Ecol 198: 155-173

Peterson CH, Summerson HC, Duncan PB (1984) The influence of seagrass cover on population structure and individual growth rate of a suspension-feeding bivalve Mercenaria mercenaria. J Mar Res 42:123-138

Pietrafesa LJ, Janowitz GS (1991) The Albemarle Pamlico coupling study. Albemarle Pamlico Estuarine Study, Raleigh, NC, Report No. 90-13

Pile AJ, Lipcius RN, van Montfrans J, Orth RJ (1996) Densitydependent settler-recruit-juvenile relationships in blue crabs. Ecol Monogr 66:277-300

Planes S, Levefre A, Legendre P, Galzin R (1993) Spatio-temporal variability in fish recruitment to a coral reef (Moorea, French Polynesia). Coral Reefs 12:105-113

Posey M, Powell C, Alphin T, Townsend E (1999) Oyster reefs as habitat for fish and decapods. In: Leckenbach MW, Mann R, Wesson JA (eds) Oyster reef habitat restoration: a synopsis and synthesis of approaches. Virginia Institute of Marine Science Press, Gloucester Point, VA

Pulliam HR (1988) Sources, sinks, and population regulation. Am Nat 132:652-661

Real L (1979) Ecological determinants of functional response. Ecology 60:481-485

Robertson DR (1988) Abundances of surgeonfishes on patchreefs in Caribbean Panama: due to settlement, or postsettlement events? Mar Biol 97:495-501

Ross SW, Epperly SP (1985) Utilization of shallow estuarine nursery areas by fishes. Pamlico Sound and adjacent tributaries, North Carolina. In: Yanez-Arancibia A (ed) Fish community ecology in estuaries and coastal lagoons. Towards an ecosystem integration. UNAM Press, Mexico, p 207-232 
Roughgarden J, Gaines S, Possingham H (1988) Recruitment dynamics in complex life cycles. Science 241:1460-1466

Ruiz GM, Hines AH, Posey MH (1993) Shallow water as a refuge habitat for fish and crustaceans in non-vegetated estuaries: an example from Chesapeake Bay. Mar Ecol Prog Ser 99:1-16

Shenker JM, Maddox ED, Wishinski E, Pearl A, Thorrold SR Smith N (1993) Onshore transport of settlement-stage Nassau grouper Epinephelus striatus and other fishes in Exuma Sound, Bahamas. Mar Ecol Prog Ser 98:31-43

Shirley MA, Wolcott TG (1991) A telemetric study of microhabitat selection by premolt and molting blue crabs, Callinectes sapidus (Rathbun), within a subestuary of the Pamlico River, North Carolina. Mar Behav Physiol 19:133-148

Thomas JL, Zimmerman RJ, Minello TJ (1990) Abundance patterns of juvenile blue crabs (Callinectes sapidus) in nursery habitats of two Texas Bays. Bull Mar Sci 46:115-125

Thrush SF, Pridmore RD, Bell RG, Cummings VJ, Dayton PK, Ford R, Grant J, Green MO, Hewitt JE, Hines AH, Hume TM, Lawrie SM, Legendre P, McArdle BH, Morrisey D, Schneider DC, Turner SJ, Walters RA, Whitlatch RB, Wilkinson MR (1997) The sandflat habitat: scaling from experiments to conclusions. J Exp Mar Biol Ecol 216:1-9

Tolimieri N (1995) Effects of microhabitat characteristics on the settlement and recruitment of a coral reef fish at two spatial scales. Oecologia 102:52-63

Underwood AJ (1981) Techniques of analysis of variance in experimental marine biology and ecology. Oceanogr Mar Biol Annu Rev 19:513-605

van Engel WA (1958) The blue crab and its fishery in the Chesapeake Bay. Part I. Reproduction, early development, growth, migration. Commer Fish Rev 20:6-17

van Montfrans J, Epifanio C, Knott D, Lipcius R, Mense D, Metcalf K, Olmi E, Orth R, Posey M, Wenner E, West T

Editorial responsibility: Kenneth Heck Jr (Contributing Editor), Dauphin Island, Alabama, USA
(1995) Settlement of blue crab postlarvae in Western North Atlantic estuaries. Bull Mar Sci 57:834-854

Victor BC (1986) Larval settlement and juvenile mortality in a recruitment-limited coral reef fish population. Ecol Monogr 56:145-160

Wahle RA, Steneck RS (1991) Recruitment habitats and nursery grounds of the American lobster Homarus americanus: a demographic bottleneck? Mar Ecol Prog Ser 69:231-243

Welch JM, Epifanio CE (1995) Effect of variations in prey abundance on growth and development of crab larvae reared in the laboratory and in large field-deployed enclosures. Mar Ecol Prog Ser 116:55-64

Welch JM, Forward RB Jr, Howd PA (1999) Behavioral responses of blue crab Callinectes sapidus postlarvae to turbulence: implications for selective tidal stream transport. Mar Ecol Prog Ser 179:135-143

Wells $H$ (1961) The fauna of oyster beds, with special reference to the salinity factor. Ecol Monogr 31:239-266

Williams AH, Coen LD, Stoelting MS (1990) Seasonal abundance, distribution, and habitat selection of juvenile Callinectes sapidus (Rathbun) in the northern Gulf of Mexico. J Exp Mar Biol Ecol 137:165-183

Wilson KA, Able KW, Heck KL Jr (1990a) Habitat use by juvenile blue crabs: a comparison among habitats in southern New Jersey. Bull Mar Sci 46:105-114

Wilson KA, Able KW, Heck KL Jr (1990b) Predation rates on juvenile blue crabs in nursery habitats: evidence for the importance of macroalgae (Ulva lactuca). Mar Ecol Prog Ser 58:243-251

Zimmerman RJ, Minello TJ, Rozas LP (2000) Salt marsh linkages to productivity of penaid shrimps and blue crabs in the northern Gulf of Mexico. In: Weinstein MP, Kreeger DA (eds) Concepts and controversies in tidal marsh ecology. New Jersey Sea Grant Publ (in press)

Submitted: May 24, 1999; Accepted: February 16, 2000

Proofs received from author(s): August 30, 2000 